\title{
Foucault e a racionalidade (neo)liberal ${ }^{2}$
}

\author{
Foucault and the (neo)liberal rationality
}

Tudo indica que o livro de Geoffroy de Lagasnerie (2012) tenha inaugurado uma nova maneira de abordar a relação entre Foucault e o neoliberalismo. ${ }^{3}$ Hostil aos numerosos trabalhos dedicados a criticar o neoliberalismo a partir do filósofo, os quais o autor define como "enunciados que nada descrevem e que não constituem, de modo algum, análises sérias do fenômeno neoliberal" (op. cit., p. 11), Lagasnerie decide posicionar sua abordagem em outra extremidade, propondo resolver o problema com a questão: "e se Foucault, ao final de sua vida, estivesse prestes a se tornar liberal?" (op. cit., p. 17). A resposta de Lagasnerie destaca-se por uma positividade de outro tipo. Sem acusar Foucault de adesão político-ideológica ao neoliberalismo, atribuiu-lhe uma adesão estratégica. A conclusão de seu livro é que, para Foucault, o neoliberalismo é "uma tática teórica que permite entrever a forma que

1 É doutor em Ciência Política pela Pontifícia Universidade Católica de São Paulo (PUC-SP). Professor no Departamento de Ciências Sociais e no Programa de Pós-Graduação em Ciência Política e Relações Internacionais da Universidade Federal da Paraíba (UFPB). Pesquisador no Centre Max Weber (CNRS, França) e coordenador do Grupo de Estudos e Pesquisas Anarquistas (GEPAn/UFPB). Entre suas publicações, destacam-se: O pensamento político de Michel Foucault, em coorganização com Salvo Vaccaro (São Paulo, Intermeios, 2016); Ditaduras: a desmesura do poder (memória, história, política), em coorganização com Ana Montoia e Telma Fernandes (São Paulo, Intermeios, 2015); Governamentalidade |Segurança, em coorganização com Salvo Vaccaro (São Paulo, Intermeios, 2014); e Confession and Political Normativity: control of subjectivity and production of the subject (Soft Power, v. 2, p. 15-38, 2015). E-mail: <nildoavelino@gmail.com>.

2 Durante a elaboração deste artigo, o autor contou com bolsa Capes de estágio pós-doutoral na Columbia University em Nova lorque (Proc. no 6.739/14-8).

3 A edição brasileira do livro de Lagasnerie, publicada em junho de 2013 pela editora Três Estrelas, foi recebida, de forma superficial, como "um livro crucial sobre Michel Foucault" (Calligaris, 2013). Ao contrário da recepção à recente edição argentina que o considerou "um uso de Foucault para elaborar um perfeito elogio à teoria de Friedrich Hayek e a do economista Gary Becker" (Gago, 2015). Veja também a reação do autor à resenha crítica de Gago (Lagasnerie, 2015). 
poderia tomar uma ofensiva contra a sociedade disciplinar: é um dos pontos de apoio possíveis para a elaboração de práticas de desassujeitamento" (op. cit., p. 175)

Além de Lagasnerie, o tema de uma "tentação liberal" em Foucault tem igualmente mobilizado certo número de estudiosos nos últimos anos em torno de um debate que produziu uma literatura considerável (Zamora, 2014; Christofferson, 2014; Behrent, 2014; 2015; Audier, 2015; Dean, 2014; 2015; Becker, Ewald e Harcourt, 2014; 2015). O propósito deste artigo é analisar o debate apresentando uma discussão crítica da sua metodologia e propondo, em seguida, outra leitura possível da análise foucaultiana do liberalismo e do neoliberalismo.

\section{Apresentação crítica do debate}

Formular uma abordagem positiva e fora dos limites da acusação ao debate sobre Foucault e o neoliberalismo não tem se mostrado tarefa fácil e, sobretudo, tem conduzido a reflexão a graves equívocos. Grosso modo, a abordagem tem sido sustentada a partir de dois métodos de análise: 1) contextualização histórico-biográfica; e 2) contextualização discursiva, descritos a seguir.

\section{Contextualização histórico-biográfica}

O fascínio de Foucault pelo neoliberalismo explica-se pelo contexto da sua militância política. Seus supostos antimarxismo e antiestatismo radicais teriam conduzido Foucault a se aproximar da deuxième gauche, a esquerda radical francesa, que, no contexto dos anos 1970, passava por um processo de neoliberalização, a adotar como armas de luta contra o gauchismo dominante estratégias neoliberais que começavam a circular, tais como a autogestão das fábricas e o empreendedorismo. Data dessa época o apoio de Foucault aos nouveaux philosophes, especialmente Max Glücksmann, seu envolvimento com a Confédération Française Démocratique du Travail (CFDT) e sua proximidade com figuras e intelectuais como Michel Rocard e Pierre Rosanvallon. Relacionados a esses problemas práticos da militância política de 
Foucault estariam os desenvolvimentos teóricos da governamentalidade, por meio da qual ele deslocou a crítica do Estado para o governo como uma maneira de desinstitucionalizar as relações de poder, redirecionando o foco da análise da dominação do Estado para as técnicas de governo, bem como a ampla retomada, nos seus cursos de 1978-1979, do "modelo da empresa" proposto pelo ordoliberalismo.

Deixando-se guiar por sua "hostilidade ao Estado" e sua "raiva ao comunismo", Foucault teria sido atraído pela deuxième gauche e sua inclinação autogestionária. "Ele assiste o fórum sobre experimentação social organizado por essa segunda esquerda [seconde gauche] em 1977 e foi bastante tocado pelo livro antitotalitário Pour une Nouvelle Culture Politique de Pierre Rosanvallon e Patrick Viveret" (Christofferson, 2014, p. 28-29). A ideia de autogestão transforma-se na principal alternativa antiestatista da deuxième gauche e em instrumento indispensável "para que a sociedade possa governar a si mesma sem a intervenção de instituições opressivas" (Behrent, 2014, p. 58).

Assim, segundo os autores, a autogestão torna-se o conceito- chave para compreender a relação de Foucault com o neoliberalismo. De um lado, "existe sua forte associação com a Second Left, particularmente com a facção minoritária de Michel Rocard, o PSU, a CFDT" (Dean, 2014). De outro, existe o fato de que, para essa esquerda, a "principal preocupação era o 'self-management' (autogestão), compreendida como a decomposição e a distribuição do Estado em instituições voluntárias" (Dean, 2014, p. 437, grifo do autor); portanto, "não a autogestão como movimento de uma direita atacando o Estado de bem-estar, mas de uma esquerda interessada em uma autonomia coletiva pós-individualista" (Dean, 2015, p. 396). E na intersecção dessas duas coisas, há a tentação neoliberal. Segundo Behrent:

a visão da deuxième gauche coincide de maneira significativa (embora limitada) com a dos liberais econômicos, na medida em que ambos identificaram a dependência excessiva ao 
Estado como uma das principais fraquezas da sociedade francesa. [...] Assim, Rosanvallon escrevia em 1976 que a "proposição autogestionária... ressoa com o projeto liberal que busca limitar o poder do Estado e para o qual o poder pertence à sociedade civil" (Behrent, 2014, p. 58-59).

Do mesmo modo, para Audier (2015, p. 203), esse novo paradigma da esquerda "implicava a reabilitação [...] da ideia do empreendedorismo", isto é, a mesma ideia encontrada no alerta que Schumpeter lançava no seu livro Capitalismo, Socialismo e Democracia, ao descrever a "marcha do capitalismo para a burocracia, na qual os gestores e administradores substituirão os empreendedores". De modo que Foucault poderá "centrar precisamente sua análise do neoliberalismo, um pouco mais tarde, sobre a ideia do indivíduo empreendedor ou do indivíduo 'empreendedor de si mesmo"' (op. cit., p. 204).

Consequentemente, vai ser possível correlacionar o modelo teórico da empresa e do empreendedorismo neoliberal com a posição política de Foucault. Trata-se de deduzir a valorização teórica do neoliberalismo por Foucault do seu engajamento político no seio da deuxième gauche francesa que, no contexto dos anos 1970, sofria a tentação do "discreto charme do liberalismo econômico" (Behrent, 2014, p. 49): a retomada do modelo teórico neoliberal da empresa encontraria confirmação ex post facto na sua militância política.

Contudo, o argumento é inconsistente ao menos em dois sentidos. Inicialmente, para dizer com Bourdieu (1986), os autores, ao pretenderem deduzir de uma ordem cronológica certa ordem lógica, incorrem na ilusão biográfica. Como se a vida em seu cursus pudesse encerrar o segredo de um sentido, de um projeto ou de uma intenção subjetiva ou objetiva. Além disso, a premissa segundo a qual seria possível encontrar coincidência política entre a deuxième gauche e o liberalismo econômico dos anos 1970 no que concerne à autogestão não encontra suficiente confirmação histórica. Com efeito, os autores contentaram-se com uma 
análise apenas superficial do debate acerca da autogestão, quando uma observação mais cuidadosa mostraria tratar-se, ao contrário, de um conceito polissêmico que permitiu abarcar concepções bastante heterogêneas, entre as quais a anarquista.

Uma análise histórica mais aprofundada mostraria, por exemplo, que a revista mais importante no debate sobre a autogestão foi concebida durante um colóquio internacional dedicado a Proudhon, em Bruxelas, no ano de 1965, quando Georges Gurvitch, Daniel Guérin e Jean Bancal decidiram fundar uma publicação destinada a se tornar "porta-voz de uma parte da esquerda radical" francesa: a revista Autogestion (Quijoux, 2011, p. 52; Weill, 1999). Os próprios idealizadores foram, eles mesmos, responsáveis pela reintrodução da concepção anarquista no debate: Gurvitch havia publicado, em 1965, um estudo que se tornou bastante difundido sobre Proudhon, intitulado Proudhon: sa vie, son oeuvre, avec un exposé de sa philosophie; no mesmo ano, Guérin publicou a antologia que se tornaria clássica: Ni Dieu, ni Maître. Anthologie de l'anarchisme - reeditada por Maspéro em 1970, 1973, 1974 e 1976; e Bancal será o autor, em 1970, de Proudhon: pluralisme et autogestion.

Embora Gurvitch tenha falecido antes do lançamento da revista em 1966, figurou nos números iniciais de Autogestion diversas análises teóricas "dos grandes percursores, tais como Charles Fourier (n. 20-21 em particular), Pierre-Joseph Proudhon, Mikhail Bakunin, considerados pelos fundadores como os pais da autogestão" (Weill, 1999, p. 31). A clareza teórico-política quanto a que conteúdo histórico emprestar à palavra autogestão revela-se também na decisão de renomeá-la em 1970, quando “o título se transforma em Autogestion et Socialisme para eliminar qualquer ambiguidade e assinalar seu pertencimento à esquerda" (op. cit.). Foi nesse clima intelectual que ocorreu o célebre $35^{\circ}$ Congresso da CFDT (que contava, entre suas figuras expressivas, com Jacques Julliard, autor de um abrangente estudo sobre o sindicalismo anarquista francês do começo do século XX intitulado Fernand Pelloutier et les origines du Syndicalisme d'Action 
Directe, publicado por Editions du Seuil em 1971). O congresso celebrizou-se na história pelo fato de ter sido a sede em que a autogestão foi aprovada pelos cédétistes como orientação geral da sua confederação (Georgi, 2003).

Vale a pena destacar as palavras emblemáticas de Maurice Joyeux, influente militante da Fédération Anarchiste, publicadas poucos dias após o congresso: "quando se pensa nos debates apaixonados desses três dias, é possível inicialmente chegar a uma conclusão. A CFDT sofreu a tentação do sindicalismo revolucionário [...]. Tradição que se inscreve fortemente em continuidade com a tendência sindical que Malatesta havia definido com lucidez em 1907" (Joyeux, 1970, grifo nosso). Joyeux, que publicou, em 1972, uma brochura intitulada Autogestion, Gestion Directe, Gestion Ouvrière e, um ano mais tarde, escreveu na célebre revista Autogestão o artigo intitulado Lautogestion Pourquoi Faire? exprime o que parece ser as notas que compuseram o tom do debate no seio da deuxième gauche da época:

a autogestão não possui nenhuma virtude em si. Trata-se de um método para administrar, organizar, definir o caráter de uma empresa. Nesse aspecto, é uma técnica que, como todas as técnicas, possui aspectos positivos ou negativos. Mas o quadro e as estruturas atuais da empresa estão construídos de tal modo para torná-la o instrumento de uma classe que, por meio dos mecanismos do lucro, da acumulação e, afinal de contas, da herança e da propriedade, permitem perpetuá-la. Nós queremos destruir esse monopólio de classe, consequentemente, queremos modificar as estruturas da empresa. As novas estruturas não se justificarão porque elas são diferentes das antigas, mas justamente porque, além da técnica propriamente dita, elas modificarão não apenas as relações econômicas, mas também morais e espirituais que os homens, que participam das diversas funções, estabelecerão entre si (Joyeux, 1970). 
Soa pouco evidente, portanto, falar em tentação neoliberal; considerando o clima intelectual da época, no qual o anarquismo francês faz-se fortemente presente, seria possível conjecturar, ao contrário, a existência de uma tentação anárquica no contexto político da deuxième gauche francesa. Mas, embora não fosse possível estar alheio a esse clima, tampouco é um fato capaz de explicar o interesse de Foucault pelo neoliberalismo.

\section{Contextualização discursiva}

$\mathrm{O}$ segundo argumento consiste em afirmar que Foucault teria encontrado no neoliberalismo uma ferramenta crítica contra os pressupostos antropológicos não apenas da esquerda, mas também do próprio liberalismo político. É o que explicaria seu interesse pelo liberalismo econômico, dos fisiocratas à Escola de Chicago. O neoliberalismo colocava-se como alternativa às sociedades de soberania e disciplinar e seus pesados sistemas jurídico e judiciário de interdição e punição, suas técnicas de sujeição e seus saberes de objetivação dos indivíduos, aspectos que haviam sido minuciosamente estudados e criticados por Foucault até a primeira metade dos 1970.

Para demonstrar a maneira pela qual o neoliberalismo teria oferecido a Foucault uma possibilidade de crítica ao poder-saber das velhas sociedades de soberania e disciplinares, aos seus regimes de punição e às suas formas de sujeição da subjetividade, os autores procederam por analogia, recuperando na obra de Foucault o sentido de conceitos e proposições trabalhados anteriormente pelo filósofo. Foi o que fez Lagasnerie com a noção de crítica: "Michel Foucault percebeu o neoliberalismo como uma das encarnações da tradição crítica. Em uma conferência de 1978 intitulada 'O que é a crítica?' [...] ele a definiu 'como a arte de não ser excessivamente governado'. É também um dos aspectos da arte neoliberal" (Lagasnerie, 2012, p. 50; 2013, p. 64). Desse modo, o sentido da noção de crítica como tática teórica de desassujeitamento do sujeito, elaborada em 1978, será doravante retomado como atitude crítica neoliberal contra as sociedades disciplinares. 
A analítica neoliberal oferece a Michel Foucault armas para desfazer o empreendimento dos modos de pensamento político, a concepção jurídica da soberania, a axiomática jurídico-dedutiva. Os conceitos de "mercado", de "racionalidade econômica", de "homo econômico" etc., foram percebidos por Foucault como instrumentos críticos extremamente potentes, permitindo desqualificar o modelo do direito, da lei, do contrato, da vontade geral etc. (Lagasnerie, 2012, p. 49; 2013, p. 65).

Não só. Seria possível até mesmo encontrar nessa atitude crítica neoliberal as razões do tournant do último Foucault em direção à subjetividade. Durante um debate organizado por Bernard Harcourt realizado em duas sessões, a primeira em 2012 e a segunda em 2013, na Universidade de Chicago, François Ewald (Becker, Ewald e Harcourt, 2011, p. 4) chegou a sustentar a existência de uma verdadeira apologia de Foucault ao neoliberalismo, especialmente por Gary Becker: "em busca de uma teoria não moral e não jurídica [...] ele encontra a solução nos escritos dos economistas" (op. cit., p. 6). Segundo Ewald, os trabalhos de Becker foram para Foucault "a possibilidade de pensar o poder sem disciplina [...]; sua teoria da regulação torna possível conduzir o comportamento dos outros sem coerção, mas por incitamento. [...] Foucault se tornou um pupilo de Gary Becker? Não sei” (op. cit., p. 8). Embora o próprio Becker tenha considerado a hipótese absurda (op. cit., p. 17), Ewald insistirá ainda nesse aspecto por ocasião de seu segundo encontro com o ex-Chicago boy. Nessa segunda sessão do debate, ele dirá, de forma laudatória, que, em razão do modelo do homo econômico de Becker, o economista teria sido considerado "um libertador por Foucault, um libertador dos modelos do passado" (Becker, Ewald e Harcourt, 2013, p. 8). Segundo Ewald, a crítica de Becker à governamentalidade assume para Foucault o mesmo estatuto filosófico da "crítica cínica": 
sim, é isso que está escrito - "le cynisme". Para Foucault isso não é ruim! Porque os cínicos, para Foucault, são pessoas que definem um novo tipo ou uma nova possibilidade de dizer verdadeiro. Para Foucault, sua crítica da governamentalidade [de Becker] produz poder da verdade sem ou fora de considerações morais (Becker, Ewald e Harcourt, 2013, p. 7).

Ewald está se referindo a uma passagem do curso Nascimento da Biopolítica, na qual Foucault afirma que a crítica neoliberal americana não é simplesmente política nem jurídica: "é uma crítica mercantil, o cinismo de uma crítica mercantil oposta à ação do poder público" (Foucault, 2004b, p. 252). A partir disso Ewald conclui um Gary Becker cínico, consequentemente, parresiasta! Trata-se de uma afirmação espantosa por sua simplicidade que, contudo, alcançará um grau de superficialidade ainda mais extraordinário com Audier quando afirma que Foucault, ao mobilizar a palavra "cinismo" a propósito da crítica neoliberal do Estado, "fala como filósofo e não emprega as palavras sem pesá-las [...]. Tudo indica que o cinismo participa aqui da atitude crítica, ela mesma indissociável, para Foucault, do liberalismo, e também do neoliberalismo sob certos aspectos (Audier, 2015, p. 286-287, grifos do autor).

Em seu livro, Audier referiu-se ao método empregado para sua leitura de um "Foucault neoliberal" como sendo uma contextualização discursiva, um método que também está presente nos demais autores empenhados na mesma tarefa. Trata-se de "ler as aulas no Collège de France sobre o neoliberalismo [...] sem seu contexto histórico, biográfico e discursivo" (op. cit., p. 129). Se a contextualização histórico-biográfica consiste em extrair sentido de uma trajetória existencial, no que concerne à contextualização discursiva, os autores operam uma verdadeira remissão lexical e de sentido. Foi dessa maneira que a noção de crítica, cujo sentido Foucault descreveu na célebre conferência de 1978 pronunciada na Société Française de Philosophie, terá seu sentido remetido 
à crítica que o liberalismo e o neoliberalismo lançaram contra o Estado e que foi analisada por Foucault em 1978 e 1979.

Assim, segundo Audier (2015, p. 291), há todo um vocabulário empregado nas aulas de 1979 no Collège de France que Foucault parece ter retomado dos "novos economistas", corrente neoliberal francesa. Não apenas a ideia de uma "filosofia analítica da política", proposta por Foucault em uma conferência de 1978, no Japão, figura como sendo "muito exatamente o tema que ele também percebe operando na crítica neoliberal americana ao Welfare" (op. cit., p. 395). Mas também a própria noção de "cuidado de si" seria apenas a repetição do "empreendimento de si" neoliberal: gestão da própria vida, técnica de elaboração da vida e fabricação pessoal de si, proteção de si mesmo, tudo isso remeteria às noções neoliberais de fabricação da liberdade, política social individual, seguridade individual e mútua (op. cit., p. 409). Entre esses e outros "ecos surpreendentes", Audier destaca a noção de "estilo" empregada por Foucault para descrever incialmente o neoliberalismo e, em seguida, as práticas de si da Antiguidade. De modo que, "entre o asceta ou o dandy ou o filósofo elaborador de si mesmo, de um lado, e o sujeito neoliberal tal como Foucault o imagina, empreendedor de si mesmo, de outro, não haveria realmente nenhum tipo de parentesco, mesmo parcial, ou, para ser mais preciso, algum ponto de passagem?" (op. cit., p. 413). Impossível não constatar, diz Audier, por meio de todas essas "estranhas ressurgências lexicais", que "o vocabulário dos cursos sobre o neoliberalismo impregnou decididamente a abordagem ulterior de Foucault" (op. cit., p. 417).

Empregando o mesmo tipo de análise, será a vez de Michael Behrent (2015, p. 379) mostrar como um termo sobre o qual Foucault deteve-se no curso Nascimento da Biopolítica evidencia "o quanto a posição neoliberal é decididamente anti-humanista e profundamente consoante com seu pensamento como um todo". Trata-se do termo máquina, utilizado pelos economistas da Escola de Chicago para caracterizar o trabalhador: "o fato de Foucault escolher usar o termo 'máquina' para descrever a 
concepção de Schultz do trabalho é indicativo da proximidade efetuada por Foucault entre a Escola de Chicago e seu próprio pensamento". Ora, basta lembrar, diz Behrent, que máquina é também um conceito-chave no livro de Deleuze e Guattari cuja edição americana foi prefaciada por Foucault, para se dar conta que "todo o léxico compreendido pelos termos 'máquina', 'tecnologia' e outros conceitos relacionados desempenham um papel crucial no conjunto do pensamento de Foucault" (op. cit., p. 380).

Além disso, Behrent aponta uma segunda e mais importante evidência da sedução de Foucault pelo neoliberalismo: trata-se da supressão antropológica do criminoso presente especialmente nas teorias de Gary Becker sobre crime e punição. Becker propôs uma análise na qual o comportamento criminoso é simplesmente descrito em termos econômicos de oferta e demanda, eliminando qualquer tipo de consideração moral e antropológica do crime e provocando o apagamento do sujeito criminoso. "O criminoso não é nada mais que absolutamente qualquer um", diz Foucault (2004b, p. 258), qualquer um que decide sustentar uma conduta criminosa. Desse modo, existiria entre a supressão antropológica realizada por Becker e a famosa "morte do homem", descrita por Foucault em As Palavras e as Coisas, uma flagrante e direta relação: "muita da sua fascinação com o neoliberalismo decorre das soluções oferecidas por ele às críticas que Foucault havia proposto em As Palavras e as Coisas contra o caráter antropológico do pensamento moderno" (Behrent, 2015, p. 383). Essa é também a conclusão de Mitchell Dean (2015, p. 399), para quem "intelectualmente Foucault demonstra mais afinidade com o neoliberalismo americano da Escola de Chicago".

Como é possível perceber, o método de contextualização discursiva explicitado por Audier, mas também empregado pelos demais autores para demonstrar a valorização teórica do neoliberalismo por Foucault, consiste em reencontrar e reabilitar o sentido discursivo de uma série de enunciados proferidos pelo filósofo ao longo de seu percurso intelectual. Assim, homóloga à contextualização histórico-biográfica, a contextualização discursiva 
busca estabelecer certa linha de continuidade, uma acumulação e sedimentação do já-dito na obra do autor. Nesse procedimento, os enunciados são tratados em sua globalidade e naquilo que possuem em comum. Perdem, portanto, sua singularidade de acontecimento discursivo para ganhar uma medida de duração: até onde se estende a repetição do seu sentido? Estabelecida a sucessão dos enunciados, bastaria deduzir dela compromissos e sentimentos mal dissimulados e inconfessos.

Nessa maneira fácil pela qual se organiza discursos futuros, assinala-se as reaparições do “já-dito” e as remissões do originário, estabelece-se a espessura do "já presente”, perscruta-se fidelidades ocultas e fatalidades discursivas, Foucault já havia alertado, há muito tempo, para dois graves problemas metodológicos que o empreendimento implica. Em primeiro lugar, a precedência, não sendo um dado irredutível, não pode servir de medida para avaliar qualquer discurso. "A demarcação das precedências não é suficiente, sozinha, para determinar uma ordem discursiva [...]. Ao enquadrar o discurso ao longo de um calendário e ao conferir uma data a cada um de seus elementos, não se obtém a hierarquia definitiva das precedências" (Foucault, 1969, p. 186). Nada mais inútil, portanto, querer estabelecer a cronologia das precedências. Mas, além da suposição ingênua dessa continuidade fácil do sentido, há também o problema das semelhanças do já-dito, das identidades textuais, da proximidade das proposições. Afinal, questiona Foucault,

em que direção e segundo quais critérios é possível afirmar: "isso já foi dito", "a mesma coisa já se encontra em tal texto", “já essa proposição é fortemente próxima daquela outra” etc.? Na ordem do discurso, o que é a identidade, parcial ou total? Que dois enunciados sejam exatamente idênticos, que sejam feitos das mesmas palavras utilizadas no mesmo sentido, não autoriza, sabemos, identificá-los absolutamente. [...] Exaustiva, a identidade não é um critério; [...] no momento em que as palavras não são utilizadas a cada vez no mesmo 
sentido ou quando um mesmo núcleo significativo é apreendido por meio de palavras diferentes: em que medida é possível afirmar que é efetivamente o mesmo problema que se apresenta [...]? (Foucault, 1969, p. 187).

Não existe, portanto, semelhança discursiva em si. Nesse aspecto, diz Foucault, toda analogia pretendida não passa de um efeito do campo discursivo na qual é apreendida, de modo que o procedimento que consiste em "buscar no grande amontoado do já-dito o texto que se assemelha 'previamente' a um texto ulterior, bisbilhotar a história para reencontrar o jogo das antecipações ou seus ecos, remontar aos germes primeiros ou descer até seus últimos vestígios", tudo isso, diz Foucault (Foucault, 1969, p. 187-188), talvez seja um passatempo divertido, mas é certamente ultrapassado e próprio a historiadores en culottes courtes.

\section{Podem liberalismo e neoliberalismo sustentar uma atitude crítica?}

O método de contextualização discursiva proposto pelos autores citados parece não resistir à crítica da arqueologia foucaultiana, devendo ser ele também abandonado com boa parte de suas conclusões. No fundo, o questionamento colocado pelos autores - por que Foucault interessou-se pelo neoliberalismo? - traz com ele o mesmo tipo de chantagem já descrito por Foucault (1994b, p. 572) a propósito da aufklärung. Trata-se de "uma alternativa simplista e autoritária": ou se aceita o liberalismo e o neoliberalismo e se permanece fiel à sua tradição, ou os acusa para dela escapar. Por essa razão, em vez de por que, seria preciso buscar saber como Foucault interessou-se pelo liberalismo e pelo neoliberalismo. A questão remete inevitavelmente para o conjunto metodológico do próprio Foucault, especialmente à genealogia, sem a qual não é possível apreender o problema de modo satisfatório. Neste artigo, compartilho do argumento de Colin Koopman, ao defender que: 
[...] a força dos conceitos de Foucault (disciplina, biopoder, cuidado de si etc.) dependem em grande medida do seu conjunto metodológico (genealogia, arqueologia, problematização etc.). Quando se separa esses conceitos do método no interior dos quais operam, eles perdem seu potencial crítico [...]. O método, pelo contrário, construído como equipamento analítico e de diagnóstico, pode passar muito bem sem os conceitos específicos descobertos na investigação (Koopman, 2013, p. 7).

Um exemplo que poderia ilustrar o argumento de Koopman é precisamente o da crítica. A partir da perspectiva genealógica, crítica é definida como atitude, isto é, um comportamento. Um tipo de comportamento constituído pela articulação irredutível entre poder, verdade e sujeito. Contudo, a genealogia demonstra que essa articulação apenas foi possível ao longo da história pela correlação entre um poder que se exerce, isto é, um excesso de autoridade, de um lado e, de outro, uma atitude de recusa, rejeição, limitação do poder e da autoridade que assume a forma de uma decisão, de uma vontade, de um apelo à coragem. A crítica como atitude é, portanto, inseparável de uma invocação da coragem que constitui sua própria condição de possibilidade: não há atitude crítica sem apelo à coragem. Será unicamente sob essa condição, diz Foucault, que a crítica poderá ser compreendida como um tipo de "inservidão voluntária", ou seja, frente a um processo de governamentalização, entendido como "prática social de sujeição dos indivíduos por meio de mecanismos de poder que sustentam uma verdade", a crítica se posicionará como "um movimento pelo qual o sujeito [...] interroga a verdade sobre seus efeitos de poder e o poder sobre seus discursos de verdade" (Foucault, 1990, p. 39).

Portanto, sem uma genealogia dos atos de coragem, não é possível apreender a atitude crítica em suas manifestações históricas. Foi o que conduziu Foucault a analisar essa forma de manifestação, sem dúvida a mais emblemática, que é a parrésia: a fala franca que ameaça, frequentemente com a morte, a própria vida 
do falante. A parrésia revela um dos aspectos fundamentais da atitude crítica: o efeito de retorno que o risco de dizer a verdade produz sobre o locutor. Quando o gesto de dizer a verdade vale tanto quanto a própria vida, não há poder capaz de impedir que uma verdade seja dita. Não é, portanto, o conteúdo da verdade, mas a atitude do locutor, ou melhor, o fato de que as condições são tais que dizer a verdade produzirá sobre o sujeito falante um efeito de retorno sob a forma de uma exigência de coragem, é isso o que caracteriza a parrésia como crítica. Como disse Foucault, a parrésia não é uma maneira de demostrar a verdade, mas "uma forma de crítica [...] sempre em uma situação onde o locutor [...] está em uma condição de inferioridade a respeito do interlocutor" (Foucault, 2001b, p. 17-18).

Falta ao liberalismo esse tipo de audácia política pelo fato de ele ter se estabelecido historicamente como um tipo de crítica interna em relação ao poder político. É o que mostra a "sociogênese" de Norbert Elias ao descrever a composição do movimento intelectual da fisiocracia: ele abrangia não apenas a pequena nobreza rural e grandes latifundiários, mas também uma parte significativa da alta administração da Corte, a noblesse de robe, financistas e as guildas de ofício.

Se essa tendência (que nem tinha nome nem organização unificada) tivesse que recebê-lo, poderia ser chamada de burocracia reformista. [...] Já a base social de onde emergiu a fisiocracia eram a corte e a sociedade de corte, onde o esforço intelectual visava a objetivos concretos específicos, tais como influenciar o rei ou suas amantes" (Elias, 1996, p. 57-58).

Portanto, a própria origem dos seus quadros sociais impediu o liberalismo de sustentar audácia política. Contudo, teria sido ele capaz de audácia teórica? Um dos aspectos destacados por Foucault na sua análise foi o da "lateralidade da crítica" do liberalismo em relação ao soberano e do neoliberalismo em relação à lei. Ou seja, não se encontra neles uma posição crítica de confronto e 
de enfrentamento, apenas um posicionamento crítico lateral. $\mathrm{Na}$ medida em que seus objetivos são o enriquecimento do Estado e o reforço da lei, o que neles se encontra é menos o gesto de uma audácia teórica do que o cálculo para a correta adequação entre meios e fins. É o que explica o fato da crítica liberal operar de maneira performativa. Como todo enunciado performativo, também os do liberalismo e do neoliberalismo dependem, em grande medida, da existência de certas instituições extralinguísticas no interior das quais posicionam-se tanto o locutor quanto o interlocutor. Como diz Searle (2002, p. 28), “é apenas por haver instituições como a Igreja, o direito, a propriedade privada, o Estado - e posições especiais do falante e do ouvinte no interior dessas instituições - que se pode excomungar, designar, doar e legar bens, declarar guerra”.

A atitude crítica, pelo contrário, é acontecimental, isto é, suas condições de possibilidade não são dadas nem pelo contexto institucionalizado, nem pelo estatuto do sujeito falante. Foucault mostrou, no seu curso de 1983, que os enunciados da atitude crítica "constituem um acontecimento irruptivo, abrindo para o sujeito que fala um risco não definido ou mal definido" (Foucault, 2008, p. 61). Além da abertura desse risco indeterminado em função das condições dadas, o sujeito falante da atitude crítica, ao contrário do enunciado performativo, não possui qualquer estatuto: ele "pode ser qualquer um", de modo que se encontra na atitude crítica "não o estatuto social, institucional do sujeito, encontramos sua coragem” (op. cit., p. 63).

Outro aspecto revelado pela genealogia da atitude crítica é ainda mais significativo. Trata-se da irredutível distância que ela guarda em relação à crítica como juízo e sua função normativa. Diferentemente da atitude crítica, os enunciados da crítica como juízo são normativos. Como mostrou Butler (2004, p. 305), essa foi a razão pela qual Foucault, na célebre conferência de 1978, insistiu em mostrar não apenas o que a crítica é, mas, sobretudo, "qual tipo de questionamento a crítica institui". A partir de Kant, Foucault aponta a existência de uma mudança (décalage) entre a 
atitude crítica (a aufklärung) encontrada no texto kantiano menor - O que é o Iluminismo? - e o modo como Kant definiu a Crítica na sua obra. Uma mudança que ele situa da seguinte forma:

[...] em relação à aufklärung [isto é, à atitude crítica], a crítica será aos olhos de Kant o que ele dirá do saber: sabes até onde podes pensar? Racionas quanto queiras, mas sabes até onde podes racionar sem perigo? A crítica dirá, enfim, que a nossa liberdade está menos no que realizamos com mais ou menos coragem e mais na ideia que fazemos do conhecimento e seus limites; consequentemente, em vez de esperar alguém dizer "obedeças!", quando se tem de seu próprio conhecimento uma ideia justa, será possível descobrir o princípio da autonomia e deixar de ouvir "obedeças!", pois o "obedeças!" estará fundado na própria autonomia (Foucault, 1990, p. 41, grifos do autor).

A oposição entre aufklärung e crítica consiste, portanto, em substituir a coragem que implica a primeira por um autorreconhecimento dos limites do saber com função normativa; uma substituição necessária ao projeto kantiano de autonomia. Se Foucault, em As Palavras e as Coisas, já havia criticado o projeto kantiano por estar fundado em uma ilusão antropológica do homem, agora, cerca de dez anos após a primeira "crítica à crítica" kantiana, Foucault realiza uma segunda crítica evidenciando que, como sublinhou Amy Allen (2003, p. 191), se "para Kant a coragem de saber característica do iluminismo é, [...] em última análise, a coragem de reconhecer os limites da nossa consciência, para Foucault, a coragem de saber é, em última análise, a coragem para reconhecer a contingência desses limites e começar a pensar além deles". É o que o próprio Foucault (1994b, p. 574) sustenta no seu ensaio Qu'est-ce que les Lumières? publicado em 1984: "trata-se de transformar a crítica exercida sob a forma da limitação necessária em uma prática possível de superação dos limites". 
A crítica como prática de superação dos limites não assume função normativa, ao contrário, "ela é genealógica em sua finalidade e arqueológica em seu método" (Foucault (1994b). Sua tarefa é mostrar que os discursos que limitam o que pensamos, dizemos e fazemos não são necessários ou inevitáveis, mas são acontecimentos históricos como quaisquer outros, e, com isso, liberar, a partir da evidência da fragilidade de uma "contingência histórica que nos fez ser isso que nós somos, a possibilidade de não mais ser, fazer ou pensar isso que nós somos, fazemos ou pensamos" (op. cit.). A tarefa da crítica é, portanto, a de "relançar, tão longe e largamente quanto possível, o indefinido trabalho da liberdade" (op. cit.). Em outras palavras, a crítica revela que a aceitabilidade daquilo que somos, fazemos e pensamos não possui outro fundamento que a arbitrariedade de um saber e a violência de um poder.

Trata-se de uma tarefa que não pode ser, evidentemente, obra do poder. Contudo, seria ainda mais perigoso entregá-la a um saber que reproduziria, com outro regime normativo, os fundamentos de uma nova aceitabilidade. É o que tem feito a crítica-juízo, de Kant a Habermas, quando se propõem buscar os fundamentos legítimos do saber. Mas, nesse momento, como pontuou Butler (2004, p. 305, grifo do autor), "a crítica se torna curiosamente acrítica em relação a seu próprio fundamento de normatividade". Desse modo, a crítica como juízo nasce debilitada pela própria normatividade que institui e em relação ao seu próprio regime de verdade.

A tarefa da crítica não pode ser, portanto, nem questão de poder, nem de saber. É uma decisão, uma vontade, é "questão de atitude" (Foucault, 1990, p. 53). Uma atitude teórico-prática que, anos mais tarde, Foucault chamou de "anarqueologia" - com o propósito de aproximá-la da anarquia, evitando confundir-se com ela, porém, sem a excluir de forma absoluta (conforme Avelino, 2010) - e que ele definiu nos seguintes termos:

não se trata mais de dizer: considerando o vínculo que me liga voluntariamente à verdade, o que é que eu posso dizer 
do poder? Mas: considerando minha vontade, decisão e esforço de desfazer o vínculo que me liga ao poder, então, o que é feito do sujeito de conhecimento e da verdade? [...] É o movimento de se liberar do poder que deve servir de revelador às transformações do sujeito e à relação que ele sustenta com a verdade. Vocês veem que tal forma de análise repousa [...] mais sobre uma atitude que uma tese. [...] É uma atitude que consiste, primeiramente em dizer para si mesmo que nenhum poder é aceitável, que nenhum poder, qualquer que ele seja, é evidente ou inevitável, que nenhum poder, consequentemente, merece ser aceito no jogo. Não existe legitimidade intrínseca do poder. E a partir dessa posição, a investigação consiste em perceber o que é feito do sujeito e das relações de conhecimento na medida em que nenhum poder é fundado em direito ou necessidade; na medida em que todo poder jamais repousa que na fragilidade de uma história, que o contrato social é um blefe e a sociedade civil um conto para crianças, que não existe nenhum direito universal, imediato e evidente que possa sempre e em toda parte sustentar uma relação de poder qualquer que seja ela (Foucault, 2012, p. 75-76).

Para Foucault a ideia de uma anarqueologia, isto é, a atitude de não aceitabilidade do poder, deve ser colocada como critério analítico "sob a forma do questionamento de todos os modos pelos quais efetivamente se aceita o poder" (Foucault, 2012, p. 77, grifos nossos). É uma atitude que questiona a aceitabilidade não apenas do contrato social imaginado pelo liberalismo político ("um blefe"), mas também a aceitabilidade da sociedade civil imaginada pelo liberalismo econômico ("um conto para crianças"). É, portanto, uma atitude que não institui nenhum regime de verdade, tampouco qualquer quadro normativo e que, consequentemente, é incompatível com as formas políticas liberal e neoliberal. 
O fato de alguns autores, especialmente Lagasnerie e Audier, terem pretendido associar o liberalismo e o neoliberalismo à atitude crítica foucaultiana, mostra apenas a que ponto pode chegar a superficialidade de uma análise. De resto, como veremos pela sua genealogia, não só essas duas tradições políticas são desprovidas de atitude crítica, como são dotadas, ao contrário, de uma racionalidade altamente normativa e de um regime de verdades deduzidos do cálculo econômico.

\section{Liberalismo como racionalidade}

Tomados em perspectiva genealógica, liberalismo e neoliberalismo constituem para Foucault acontecimentos discursivos (Foucault, 1969). Assim como a loucura, o hospital, a prisão e a sexualidade, liberalismo e neoliberalismo constituem acontecimentos discursivos que determinam aquilo que somos, fazemos e pensamos em nossa atualidade. A partir disso, a tarefa da crítica seria a de questionar como foram possíveis a sua aceitabilidade, não para denunciar sua maldade essencial ou elogiar a suavidade dos seus limites, mas para revelar na contingência da sua história a fragilidade capaz de franquear novas possibilidades de ser, fazer e pensar em nossa atualidade.

Uma particularidade da genealogia é que sua compreensão dos acontecimentos discursivos exige bem mais do que um posicionamento contra ou a favor. Ocorre com o liberalismo e o neoliberalismo o mesmo que com a sexualidade: é preciso pensá-los como acontecimentos discursivos cuja existência só é possível a partir do sujeito de suas práticas. Então, não se trata de combatê-los como falsos ou aceitá-los como verdadeiros, mas de mensurar os efeitos do seu investimento sobre a subjetividade dos indivíduos. Sendo o liberalismo e o neoliberalismo, tanto quanto a sexualidade, indissociáveis daquilo que somos, fazemos e pensamos no presente, melhor que atacá-los ou defendê-los, seria preciso perceber historicamente quais foram às condições de possibilidade que permitiram seus efeitos de determinação sobre nossa subjetividade. 
Foi nesse sentido que Foucault não se engajou em nenhuma das atitudes em relação ao neoliberalismo que estavam em voga na sua época. Havia, grosso modo, duas maneiras de se reportar ao neoliberalismo. Ou bem se referia a ele de uma maneira ideológica, isto é, pela denúncia e pela acusação (foi um modo muito presente no debate militante dos 1970, no qual o neoliberalismo figurava como "tirania mascarada" cujo prefixo "neo" ocultava a mesma dominação do velho liberalismo, porém camuflada) - essa abordagem, em termos ideológicos, ficou bastante conhecida especialmente com Herbert Marcuse (1997), para quem é o próprio liberalismo que gesta o fascismo.

E, ao lado dessa abordagem como denúncia e acusação, existiu, também, outra maneira de se reportar ao neoliberalismo oposta a Marcuse e que consistia em dar a ele não uma imagem ideológica, mas uma imagem ideal de validação das suas liberdades diante da ameaça totalitária. Entre os autores que se colocam nessa abordagem, poder-se-ia citar Rawls (2000), Habermas (2000), Rorty (1999), Dahl (2012), Arendt (2009) e Lefort (2011). ${ }^{4}$ De maneira distinta, e muitas vezes oposta, estes autores irão se referir ao liberalismo validando nele seu ideal de liberdade política, econômica, intelectual, em contraste com a opressão totalitária.

Quanto à atitude de Foucault, ela não foi nem ideológica, nem ideal; não foi validadora, mas tampouco foi denunciativa. Foucault recusou-se a ver no neoliberalismo tanto um ideal de liberdades quanto uma ideologia de dominação: sua atitude em relação ao liberalismo foi descritiva e analítica. Assim, enquanto o debate e a crítica em torno do neoliberalismo estavam polarizados entre a denúncia ideológica e a validação ideal das liberdades liberais, como sublinhou Bonnafous-Boucher (2001), Foucault assume

4 Certamente não é possível classificar Arendt e Lefort sob a tradição política liberal, mas seria possível sugerir que ambos partilham do mesmo tipo de condenação moral do totalitarismo: homem-massa, indistinção entre público e privado, absorção da sociedade civil pelo Estado, entre outros, explicariam o fenômeno totalitário alemão e soviético. Uma explicação que, além da defesa do constitucionalismo e da rule of law, encontra paralelos em Hayek (2006) e se distancia fortemente de Foucault. Para uma discussão acerca das diferenças Arendt-Foucault, veja Esposito (2006). 
uma atitude e um posicionamento estranhos e atípicos. Em 1979, durante seu curso Nascimento da Biopolítica, ele afirma: "ao falar da governamentalidade liberal não quero, ao utilizar essa palavra 'liberal', sacralizar ou valorizar este tipo de governamentalidade liberal. Não quero dizer tampouco que não seja legítimo odiar o Estado" (Foucault, 2004b, p. 197). Assim, sua posição toma outra direção. Por ocasião de uma mesa-redonda organizada em 1978 pela historiadora francesa Michelle Perrot, em torno do panóptico de Jeremy Bentham, Foucault sustentou o seguinte: "o liberalismo não é, evidentemente, nem uma ideologia nem um ideal. É uma forma de governo e de racionalidade governamental muito complexa. E acredito ser dever do historiador estudar como essa racionalidade política pôde funcionar, sob qual preço e usando quais instrumentos" (Foucault, 2001a, p. 855).

Portanto, nem uma ideologia a ser desmascarada, nem um ideal a ser valorizado: o liberalismo e o neoliberalismo constituem uma racionalidade de governo. Trata-se de uma definição um tanto enigmática e completamente deslocada dos debates em voga. O que significa dizer que o liberalismo é uma racionalidade governamental? O que é uma racionalidade? Como salientou Gabriel Cohn (2003, p. 231) a propósito de Max Weber, em termos sociológicos, quando se fala em racionalidade, fala-se necessariamente em ação: racionalidade é sempre uma ação orientada racionalmente para determinado fim. Racionalidade é uma ação na qual existe a mais perfeita e eficaz articulação entre os meios empregados para atingir um fim almejado. Nesse sentido, pode-se falar em racionalidade religiosa ou em racionalidade musical, na medida em que encontramos nesses campos ações nas quais ocorre a adequação ótima entre meios e fins.

Quando Foucault fala em racionalidade política, é esse mesmo sentido que ele procura discernir ao abordar, por exemplo, o surgimento da razão de Estado na obra de Giovanni Botero:

“a razão de Estado [...] é o conhecimento dos meios próprios para fundar, conservar e aumentar um domínio”. [...] Quer 
dizer que ele [Botero] faz da razão de Estado o tipo de racionalidade que permitirá manter e conservar o Estado a partir do momento em que ele está fundado, em seu funcionamento cotidiano, em sua gestão diária (Foucault, 2004a, p. 243).

A ideia propriamente moderna de racionalidade política nasce com os teóricos da razão de Estado, ao colocarem a exigência de uma adequação ótima entre meios e fins no exercício do poder político. Portanto, dizer que o liberalismo é uma racionalidade governamental implica apreendê-lo como uma prática na qual se encontra a adequação ótima entre princípios de governo, técnicas de poder e a conduta dos indivíduos. Para Foucault, é esta adequação ótima entre meios e fins na prática governamental o que faz a especificidade histórica do liberalismo.

Trata-se de um aspecto importante. Para Foucault, aquilo que é peculiar, relevante e específico na história do liberalismo não é a valorização da liberdade, tampouco é o exercício da opressão; mas é sua configuração enquanto racionalidade política governamental. Daí a possibilidade de delimitá-lo a partir dessa especificidade; uma delimitação que desconsidera, consequentemente, todo primado das liberdades individuais e do Estado de direito tradicionalmente evocados em sua defesa, bem como todas as denúncias de opressão contra ele dirigidas. Nada disso está na especificidade histórica do liberalismo, pois o que se encontra nela é, segundo Foucault, sua configuração como racionalidade política governamental, isto é, como prática refletida sobre a maneira como os homens governam uns aos outros. Esse é o ponto de partida de Foucault: um ponto de partida estritamente histórico e não valorativo.

A apreensão do liberalismo e do neoliberalismo como racionalidade corresponde à proposição de Foucault em abordá-los como acontecimento discursivo. É o que ele trata de evidenciar minuciosamente logo no início do curso de 1979. Em primeiro lugar, diz, o liberalismo e o neoliberalismo integram uma análise 
do governo entendido em sentido bastante limitado como exercício da soberania política, ou seja, não o governo das condutas, mas o governo do Estado. A partir disso, trata-se de analisar não a prática governamental concreta, mas a instância reflexiva "na prática de governo e sobre a prática de governo"; trata-se, diz Foucault, do "estudo da racionalização da prática governamental no exercício da soberania política" (Foucault, 2004b, p. 4). A abordagem tem por objetivo mostrar como surgiram historicamente certos conceitos clássicos da filosofia política, tais como sociedade civil, contrato, povo, Estado, súditos etc., que determinam, em grande medida, não apenas o pensamento político moderno, mas também a própria prática política no presente.

\section{Economia política como regime de verdades do liberalismo}

A primeira forma de racionalização da soberania política foi a razão de Estado organizada em torno de três elementos articulados entre si: uma polícia dotada de objetivos internos ilimitados, uma diplomacia dotada de objetivos externos limitados e o mercantilismo equipado com uma forma de racionalidade governamental que estabelecia, por sua vez, um crescimento interno ilimitado do Estado pelo aumento da população e sua limitação externa pelo mecanismo da concorrência interestatal. Se, de um lado, o princípio de limitação externa dos Estados foi responsável pelo fim do sonho imperial e o nascimento da Europa pelo estabelecimento de uma balança comercial, de outro, o princípio de crescimento interno ilimitado estabeleceu o despotismo do Estado de polícia. Como mostrou Foucault (2004a), os autores mercantilistas e cameralistas, que foram também grandes pensadores da ciência da polícia, defenderam a ideia de que se a população fosse suficientemente adestrada, repartida, distribuída, fixada de acordo com mecanismos disciplinares, produzir-se-ia, a partir desse enquadramento disciplinar, o aumento das riquezas do Estado.

Para o mercantilismo, a população aparecia essencialmente como força produtiva e na condição jurídico-política de súdito 
diante do poder ilimitado do soberano. Uma condição que, ao longo da história, provocou algumas tentativas de limitação do poder da razão de Estado, entre as mais importantes a limitação religiosa pela tradição dos espelhos dos príncipes (Senellart, 2006), bem como a extensa reflexão jurídico-política encontrada no jusnaturalismo, contratualismo, constitucionalismo. Assim, direito natural, contrato originário, leis fundamentais estão entre as inúmeras formas de limitação e controle jurídico-político do exercício do poder soberano. O que é comum a essas formas limitativas do poder é sua posição de exterioridade com a soberania. Como nota Foucault, foram, em grande medida, formas-limitações que assumiram o caráter negativo da objeção e do questionamento, muitas vezes dramático, do poder, procurando definir sua legitimidade, denunciar suas usurpações, questionar sua imposição de obediência, indagar sua justiça. Foram "limites exteriores ao Estado [...] que vêm de Deus, ou que foram estabelecidos de uma vez por todas na origem, ou que foram formulados numa história remota" (Foucault, 2004b, p. 11).

Houve, contudo, outra forma de limitação do poder da razão de Estado; limitação que, ao contrário da religiosa ou da jurídica, não assumiu uma posição exterior de contraposição, não se colocou vis-à-vis com o soberano, não denunciou suas injustiças e tampouco questionou suas imposições. Essa forma foi a da economia política que sine ira et studios transforma-se na nova racionalidade governamental. A limitação interna da economia política não indaga sobre a legitimidade do poder e tampouco se posiciona contra o poder soberano; levanta unicamente o problema da sua inadequação e da sua inabilidade. É, portanto, essa forma de limitação interna que marca o momento histórico preciso em que a racionalidade liberal começa a atuar, não se opondo ao poder, mas colocando em evidência que "governar demais era, no fundo, não governar; governar demais era induzir resultados contrários aos resultados desejados" (Foucault, 2004b, p. 15). A racionalidade liberal nasce quando o governo excessivo passa a ser considerado prática irracional, isto é, como ação em 
que os meios empregados são inadequados aos fins almejados. Esse momento histórico foi quando os fisiocratas descobriram a existência de mecanismos espontâneos e naturais da economia, em relação aos quais qualquer governo deveria respeitar caso não quisesse produzir resultados opostos aos almejados. Assim, diante da economia, dos seus processos, da regularidade das suas leis, o governo, cuja função é precisamente governar, deveria cessar de ser governo; deveria deixar livre fluxo, livre movimento ao mercado.

Com os fisiocratas, e notadamente a partir de François Quesnay, começa a surgir uma área, uma região, uma parte da realidade social em que o governo não deve governar, não deve intervir: trata-se do comércio em relação ao qual "basta o governo zelar pelo crescimento das rendas dos bens do reino, não entravar a indústria e deixar aos cidadãos a facilidade e a escolha das despesas" (Quesnay, 1983, p. 338). É o nascimento do laisser-faire, laisser-passer (deixar fazer, deixar passar), consolidado em seguida pela teoria da mão invisível de Adam Smith para indicar um processo espontâneo a partir do qual o indivíduo, ao perseguir seus próprios interesses, é conduzido a promover o interesse da sociedade. De tal modo, diz Smith, que "o estadista que tentasse orientar pessoas particulares sobre como devem empregar seu capital [...] assumiria uma autoridade que seguramente não poderia ser confiada nem a uma pessoa individual nem mesmo a alguma assembleia ou conselho" (Smith, 1983, p. 380). A mão invisível indica, portanto, um tipo de autorregulação do mercado estabelecido por um processo natural sobre o qual o governo não deve intervir, sob pena de produzir efeitos contrário aos almejados.

O significativo é que, a partir do estabelecimento dos saberes da economia política, Foucault demostra a operacionalidade da sua definição do liberalismo como racionalidade governamental: quando os fisiocratas e os economistas (Quesnay, Adam Smith etc.) afirmam que existem processos econômicos naturais e espontâneos que todo governo é obrigado a respeitar, então, questiona Foucault, com isso estão afirmando que é preciso dar aos homens 
liberdade de agir? Ou que o governo deve ser menos autoritário? Ou que se deve reconhecer os direitos e as liberdades individuais? A resposta é negativa.

O que os fisiocratas deduzem disso é que o governo deve conhecer, em sua natureza íntima e complexa, esses mecanismos econômicos. Uma vez que os conhece, deve respeitá-los. Mas respeitá-los não quer dizer que adotará uma armadura jurídica em respeito às liberdades individuais e aos direitos fundamentais dos indivíduos. Significa simplesmente que o governo deve armar sua política de um conhecimento preciso, contínuo, claro e distinto do que se passa na sociedade, no mercado, nos circuitos econômicos. De modo que a limitação de seu poder não se dará em respeito à liberdade dos indivíduos, mas pela evidência da análise econômica que ele saberá respeitar. O governo se limita pela evidência, não pela liberdade dos indivíduos (Foucault, 2004b, p. 63).

O que se encontra na formação do liberalismo é algo bem mais complexo, portanto, que simplesmente uma liberalização ou dominação. Encontra-se o estabelecimento de um novo regime de verdades pela economia política a partir da qual o mercado servirá como mecanismo de veri-dictio, isto é, dispositivo que dita, prescreve, impõe a verdade que irá limitar internamente a prática governamental. Isso significa duas coisas: em relação à prática governamental, de um lado, a economia política estabelecerá "os tipos de discursos considerados verdadeiros; os mecanismos e instâncias que permitirão distinguir os enunciados verdadeiros ou falsos [...]; as técnicas e procedimentos valorizados para obtenção da verdade; o estatuto dos que têm a tarefa de dizer aquilo que funciona como verdadeiro" (Foucault, 1994a, p. 112). E, de outro lado, o mercado, que, durante toda a Idade Média, funcionou como lugar de justiça ou de jurisdição, se tornará um lugar de veridicção, um dispositivo de saber que revela e dita o verdadeiro, 
um instrumento para a constituição de "certo direito da verdade a partir de uma situação de direito" (Foucault, 2004b, p. 37), e que armará a economia política com o poder de determinar o que o governo deve ou não deve fazer. Armado com os saberes da economia política, o mercado se instituirá como legislador diante das práticas governamentais - função que, mais tarde, o neoliberalismo alçará em tribunal.

Desse ponto de vista, afinal, o que é liberalismo? "É um novo tipo de racionalidade na arte de governar, um novo tipo de cálculo que consiste em dizer e fazer o governo dizer: eu aceito, eu quero, eu projeto, eu calculo que não é necessário tocar em nada disso [que é o mercado]. É isso o que, creio, chama-se "liberalismo"' (Foucault, 2004b, p. 22-23). Consequentemente, considerado como limitação da atividade governamental, o liberalismo não proclama a valorização das liberdades individuais; reclama simplesmente a proteção de uma economia de mercado dotada de processos naturais e espontâneos. Foucault diz ironicamente que, no fundo, não se deveria falar em liberalismo, mas em naturalismo, tendo em vista que na sua história o que se encontra não é o respeito às liberdades, mas o respeito às naturalidades do mercado, da economia, da divisão do trabalho etc. $\mathrm{O}$ que existe na história do liberalismo são naturalidades, não liberalidades. Sobretudo, o que é evidente historicamente é sua configuração enquanto racionalidade governamental: o liberalismo é um tipo de prática governamental que, pela primeira vez na história, foi obrigado a tudo conhecer em detalhe, em profundidade, de maneira clara, precisa e exaustiva. O liberalismo foi obrigado a conhecer todos os processos sociais, políticos, religiosos e morais, de maneira a governá-los conforme as naturalidades da economia.

Segundo Foucault, nenhum outro regime político na história jamais assumiu essa configuração racional; apenas o liberalismo configurou-se como um tipo de governo que, antes de tudo, pensa e reflete sobre a natureza das coisas, a liberdade dos homens, e a melhor maneira de conduzir estas coisas e estes homens. É nesse sentido que Foucault irá chamar o liberalismo de tecnologia 
política, isto é, uma prática que comporta tanto um aspecto técnico quanto um aspecto lógico, epistemológico, reflexivo. São essas duas dimensões, técnica e reflexiva, que se encontram compreendidas no termo tecnologia. Entendido nesse sentido, o liberalismo é tanto uma maneira de fazer quanto um modo de refletir sobre as coisas; portanto, uma racionalidade. Sob esse aspecto, o liberalismo mostra-se como um acontecimento discursivo irredutível na história das sociedades ocidentais.

\section{A governamentalização do Estado}

Uma questão se coloca: sendo o liberalismo uma racionalidade de governo, de que maneira a racionalidade liberal produziu sua expansão? Para dizer em termos weberianos: como se deu o "processo de racionalização" da racionalidade liberal? De que maneira a lógica política liberal foi racionalizada, isto é, expandiu sua racionalidade até recobrir em grande medida as maneiras de ser e de fazer a política? O propósito de Foucault é, à primeira vista, semelhante ao de Max Weber. Em sua obra clássica, Weber colocou a seguinte questão: considerando a mentalidade econômica própria do capitalismo, isto é, aquela atitude que encara o trabalho como uma vocação, como um fim em si mesmo, e que implica um conjunto de hábitos mentais do trabalhador: capacidade de concentração, sentimentos de obrigação, conduta calculista direcionada para maiores ganhos de salário, autocontrole de si mesmo, todos esses hábitos sem os quais o capitalismo não teria sido possível; em suma, de que maneira esse conjunto de hábitos mentais, que fazem a mentalidade econômica do capitalismo, o seu espírito, foram racionalizados, isto é, tornaram-se a conduta dominante? Como se sabe, Weber (1997) encontrou uma resposta na Reforma Protestante como acontecimento histórico decisivo para a expansão da mentalidade econômica própria do capitalismo.

Seria possível afirmar que Foucault propõe algo semelhante, modificando, entretanto, os termos da questão e evitando o nível de generalização weberiana. Como sublinhou Colliot-Thélène (2009, p. 171), ao contrário de Weber, para Foucault não está em 
questão a mentalidade econômica, mas um tipo de racionalidade governamental. Além disso, a análise é bem mais específica. Diferente de Weber, Foucault não está interessado na conduta em si, mas nas formas de condução, isto é, nos procedimentos concretos pelos quais se conduz a conduta dos indivíduos e que não se confundem com um processo de racionalização global de uma sociedade ou cultura. Portanto, considerando a racionalidade liberal em sua especificidade, trata-se de percebê-la como um acontecimento histórico irredutível em relação à "grande história da razão ocidental". Por exemplo, quando se faz a história da razão, encontra-se alguns acontecimentos históricos fundamentais e irredutíveis, tais como o aparecimento da reflexão de Kepler, Galileu, Descartes. Para Foucault, nessa grande história da razão, o aparecimento da racionalidade do liberalismo possui a mesma importância e a mesma irredutibilidade. Trata-se de um acontecimento histórico decisivo e específico que marcou o nascimento de uma maneira inteiramente nova como os homens governam uns aos outros: com o liberalismo, surge um tipo inteiramente inédito de racionalidade governamental.

Desse modo, para Foucault a questão é: como esse modo inédito de governar os homens foi racionalizado? Como as racionalidades governamentais próprias do liberalismo predominaram sobre nossa prática política? Para responder a essa questão, Foucault não saiu em busca de uma ideia matriz como fez Weber, mas forjou um tipo de abordagem chamado governamentalidade: uma proposta de estudos para compreender a tendência verificada nas sociedades ocidentais que faz predominar um tipo específico de poder, o poder de governo, em detrimento de outros (poder religioso, soberano, disciplinar etc.). Ao colocar em proeminência esse tipo de poder não significa que o poder governamental dispense todos os demais; mas que, ao contrário deles, o poder político adotará como forma principal de saber a economia política no sentido a ela atribuído por Rousseau, isto é, como arte de governar. A predominância do poder governamental e da economia política como arte de governar foi responsável, ao longo dos séculos, por 
constituir um conjunto de instituições, procedimentos, análises e reflexões, cálculos e táticas cujo resultado foi a transformação do Estado monárquico e absolutista no Estado liberal. Desse modo, o propósito da governamentalidade é o de "indicar, descrever e analisar como foi possível, na modernidade, uma condição, um estado, uma situação na qual se é governado por meio de saberes econômicos [...]. Como foram possíveis as democracias liberais e neoliberais e a qual preço?" (Avelino e Vaccaro, 2014, p. 7).

A governamentalidade possui uma perspectiva histórica de investigação que poderia ser resumida, grosso modo, da seguinte forma: existiram na história das sociedades ocidentais três grandes formas, três economias do poder político, por meio das quais o exercício da soberania política foi organizado. A primeira localiza-se no final da Idade Média, quando o exercício do poder soberano foi organizado em torno do texto religioso. A Bíblia torna-se uma espécie de manual político: dela deveriam ser extraídos os princípios, as máximas e os exemplos por meio dos quais o príncipe deveria conformar sua conduta e o exercício do seu poder. O príncipe, dizia-se, deveria ser como um espelho e refletir na sua própria pessoa, no seu próprio comportamento, as grandes virtudes cristãs de fé, esperança, caridade e amor contidas nas santas Escrituras. Estas virtudes deveriam reluzir, resplandecer na pessoa e na conduta do príncipe como se ele fosse um espelho. Esse modo de governar ficou conhecido como espelhos políticos (les miroirs politiques), um gênero literário surgido no século XII cujos trabalhos mais representativos são o Policraticus (1159), de João de Salisbury, e De Regno (1271), de Tomás de Aquino (conforme Canning, 1996).

Em seguida, com o fim da tradição política dos espelhos, surge outra maneira de exercer a soberania política que consistia não mais em indexar a conduta do príncipe em torno do texto religioso, mas em torno de um objeto que estava apenas nascendo e cujo nascimento, como é sabido, transformou amplamente a vida dos homens: o Estado. Para ser mais preciso, em seu nascimento, o Estado não foi percebido como um objeto tal como 
hoje. Nesse momento, o Estado, como o próprio nome diz, indica simplesmente uma condição dada: Estado indica a condição de prosperidade, paz e ordem do reino. Assim, governar segundo o Estado indica que o exercício do poder tem por objetivo o de manter o Estado do reino, isto é, conservar sua condição. Foi da necessidade de conservar as condições políticas do reino, o seu status, que nasceu o que ficou conhecido na história com o nome de razão de Estado. Se o príncipe pretende conservar o Estado do seu reino, ele deverá governar segundo uma razão de Estado que é simplesmente o conjunto dos conhecimentos acerca dos meios necessários para sua conservação. Como indicou Meinecke (1973, p. 11), "a razão de Estado consiste, portanto, no conhecimento que o Estado tem dele mesmo e do seu ambiente, e, consequentemente, na escolha das máximas para sua ação”. Foi a segunda grande forma do exercício do poder político no Ocidente.

Como se sabe, a razão de Estado assume imediatamente uma forma absolutista e centralizada; o príncipe torna-se a grande figura em torno da qual gravita todo o encargo da conservação do Estado. Ele tem, portanto, uma tarefa enorme, imensa, vital, na medida em que depende dele, da sua habilidade, força, fortuna, virtù, a vida ou a morte da República. Na razão de Estado, o príncipe é essa figura unitária, solitária, única, que deverá saber reinar para conservar seu Estado. Embora Maquiavel não possa ser considerado teórico da razão de Estado (conforme Senellart, 1992), a publicação de O Príncipe provocou o surgimento de um tipo de literatura antiMaquiavel (conforme Thuau, 2000), que afirmará precisamente o contrário: se é verdade que o príncipe reina único e solitário do alto do seu trono, no entanto, é igualmente verdade que o príncipe não governa. Reinar, diz esta literatura, não é o mesmo que governar. Se apenas o príncipe reina, comanda, ordena, de maneira única, de outro lado, o exercício do governo não é jamais unitário, mas é múltiplo. Muitos outros, além do príncipe, exercem esse tipo de poder governamental: o pai de família, o professor, o médico, o líder religioso etc. Portanto, se 
é verdade que existe unidade no comando real, existe pluralidade no exercício do governo.

Essa literatura antiMaquiavel introduz, pela primeira vez na história, uma distinção entre reinar, comandar, exercer a soberania política, e governar. Quando um pai de família governa não está, evidentemente, exercendo um poder soberano, exerce, ao contrário, um poder de governo: poder morfologicamente distinto do poder soberano, na medida em que não consiste simplesmente em impor a lei. Aquilo que o governo faz é conduzir condutas, tarefa muito distinta: um professor conduz a conduta dos alunos, um pastor a conduta de seus fiéis, um pai conduz a família. Desse modo, a partir dessa literatura antiMaquiavel, a prática do governo começa a surgir como uma ação específica e que não encontra seu ponto de explicação nem na Bíblia, do lado de Deus, nem na razão de Estado, do lado do príncipe; uma ação que começa a ser percebida não somente como distinta e separada da soberania, mas também como sendo importante, suplementar e independente em relação a ela.

Em um dos mais famosos livros desta literatura antiMaquiavel, escrito em 1740 pelo rei da Prússia Frederico II, o Grande, intitulado $\mathrm{O}$ anti-Maquiavel, encontra-se uma passagem reveladora desta mudança de percepção sobre as práticas de governo na época. Frederico II afirma que:

Maquiavel também quer que um príncipe não deve deixar-se governar, para que não se possa presumir que alguém tenha suficiente ascendência sobre seu espírito para fazê-lo mudar de opinião. De fato tem razão; mas afirmo que não há ninguém no mundo que não se deixe governar, uns mais, outros menos. Conta-se que certa vez a cidade de Amsterdam foi governada por um gato. Por um gato? - dirão. Como uma cidade pode ser governada por um gato? Se seguirdes a gradação de favores, sereis capazes de julgar. O primeiro burgomestre da cidade tinha o primeiro voto no conselho e lá era muito estimado. Esse primeiro burgomestre tinha 
uma mulher cujos conselhos ele seguia cegamente; uma serviçal tinha influência absoluta sobre o espírito daquela mulher, e um gato, sobre o espírito da serviçal; portanto era o gato que governava a cidade (Frederico II, 2014, p. 113).

Sem dúvida, trata-se de uma anedota contra Maquiavel, mas que possui implicações políticas importantes ao pontuar uma pluralidade ascendente nas práticas de governo. Em todo caso, correlativo ao surgimento dessa literatura política começa, também, uma intensificação e proliferação de uma literatura moral sobre as boas maneiras, isto é, sobre os problemas ligados à condução das condutas: condução das almas, das crianças, condução dos indivíduos de modo geral. Até aquele momento, o poder político jamais havia se ocupado do problema da condução das condutas dos indivíduos; mas eis que este problema explode, e explode de tal maneira que, segundo Foucault (2004a, p. 236), todo o século XVI pode ser visto como a "era das condutas, a era das direções, a era dos governos". Foi nesse mesmo período que Norbert Elias mostrou como o surgimento de uma vasta literatura preocupada precisamente com o "bom comportamento" evidencia o quanto o problema da conduta nas sociedades europeias da época do Renascimento estava assumindo uma importância extraordinária:

neste momento, a situação muda. Aumenta a coação exercida por uma pessoa sobre a outra e a exigência de "bom comportamento" é colocada mais enfaticamente. Todos os problemas ligados a comportamento assumem nova importância. [...] E é neste contexto que surgem os trabalhos de Erasmo, Castiglione, Della Casa e outros autores sobre as boas maneiras (Elias, 1996, p. 91).

Desse modo, de um lado, uma literatura antiMaquiavel enfatizando a importância do governo das condutas para o exercício da soberania e, de outro, uma literatura arduamente ocupada com o problema ordinário dos comportamentos, sua correta 
uniformização, integração, pacificação etc. Nessa junção Foucault localizou a inflação das práticas de governo responsável pela expansão da racionalidade liberal. Como observou Bonnafous-Boucher (2001), Foucault considerou o governo como sendo o motor do liberalismo. Após promover uma ampla e inédita reconstituição conceitual, o governo torna-se a regra interna do liberalismo. Esta reconstituição ampla do conceito do governo assumiu a forma de um enorme processo que Foucault chamou de governamentalização do Estado: um processo por meio do qual o liberalismo faz o conceito de governo explodir em todos os âmbitos da prática política. O resultado foi a transformação do Estado unitário e centralizado na figura do príncipe em um Estado descentralizado, não mais indexado na figura do príncipe, mas agora indexado na conduta dos governados. Esse Estado, que ainda é o nosso, Foucault chamou de Estado de governo ou governamentalizado. Trata-se da terceira grande economia do exercício do poder na história das nossas sociedades.

Em resumo, na história política das sociedades ocidentais encontram-se três grandes economias no exercício do poder soberano: a primeira é a tradição dos espelhos do príncipe, a segunda é a razão de Estado, e a terceira seria a nossa forma atual: um Estado governamentalizado, no qual o poder de governo ganha proeminência sobre todos os outros. Foi esse processo de governamentalização do Estado o que permitiu a expansão da racionalidade liberal; processo no qual o governo torna-se, segundo Foucault, a regra interna e o motor do liberalismo. E isso a tal ponto e com tanta intensidade que o liberalismo chegou mesmo a sonhar com a "debilitação do Estado até o limite de fazê-lo desaparecer por completo, porém sem jamais colocar em questão o conceito de governo que é por ele retomado e reconstituído" (Bonnafous-Boucher, 2001). É o que se verifica, por exemplo, quando Thomas Paine (1989, p. 140) defende a abolição do "governo formal" para que, em seu lugar, a sociedade possa agir para o interesse e a segurança comuns, visto não ser "o governo nada mais do que uma associação nacional agindo com base nos 
princípios da sociedade" (Paine, 1989, p. 143). É o marco de nascimento da sociedade civil, não como o outro do Estado, mas como tecnologia de governo.

Para descrever o desenvolvimento histórico desse Estado governamentalizado pela racionalidade liberal, Foucault propôs os estudos da governamentalidade. Trata-se de investigar a maneira pela qual a governamentalidade, ou as diversas racionalidades governamentais, imprimiu essa tendência na nossa prática política que, até nossos dias, não cessou de conduzir para uma direção que coloca em proeminência o poder de governo entendido como condução das condutas, em detrimento do Estado entendido como instituição centralizada. Tendência que constitui, segundo Foucault, um dos traços mais fundamentais das nossas sociedades políticas, responsável por transferir o exercício do poder político da esfera exclusiva do monopólio da violência e inseri-lo também na ordem do governo, isto é, nas práticas de condução da conduta dos indivíduos. A partir disso, é possível perceber que não é o Estado que exerce o poder político e que administra com exclusividade a dominação política. Desde o velho liberalismo até nossos dias, uma série de saberes e técnicas jamais cessou de indexar o exercício da dominação política na própria conduta dos governados.

\section{As três racionalidades do liberalismo}

O processo de governamentalização do Estado teve uma importância fundamental para a sobrevivência do Estado moderno: o velho Estado unitário e centralizado inventado pela razão de Estado não teria sobrevivido aos novos e complexos desafios colocados pelo surgimento da população e da economia política. Foi graças à governamentalização que o Estado pôde sobreviver e que a racionalidade governamental do liberalismo pôde triunfar como prática política dominante. Mas a questão é: como e com quais instrumentos o liberalismo promoveu a gorvernamentalização do Estado? Para retomar a expressão de Donzelot (2005), ao buscar formular uma resposta Foucault revelou "a inteligência 
do liberalismo". Encontra-se no processo de governamentalização do Estado a superposição de três tipos de racionalidades distintos: da razão de Estado; de um tipo de poder individualizante, o poder pastoral; e a de um poder totalizante que Foucault chamou de biopoder. Estas três racionalidades encontram-se superpostas na prática política liberal e constituem propriamente sua economia de poder.

Quadro 1 - Economia do poder liberal

\begin{tabular}{c|c|c|c}
\hline & 1) Razão de Estado & 2) Poder pastoral & 3) Biopoder \\
\hline Forma: & Anatomopolítica & Fisiologia moral & Biopolítica \\
\hline Alvo: & Corpo & Desejo & População \\
\hline Técnica: & Dispositivos disciplinares & Práticas de introspecção & Mecanismos de segurança \\
\hline Finalidade: & Produção de corpos úteis e dóceis & Produção de sujeitos & Produção de forças vitais \\
\hline
\end{tabular}

Elaboração própria.

O quadro 1 permite visualizar a complexidade da economia de poder do liberalismo e o tipo de superposição que ela promove. Foucault mostrou que a emergência da economia política provocou uma duplicação do sujeito da prática política: ele cessa de ser meramente o súdito sujeito ao poder soberano para tornar-se também parte de uma população sujeita à gestão governamental. Trata-se de uma duplicação que, além de não excluir os elementos constitutivos do poder da razão de Estado do século XVII (disciplinas), coloca também a economia do século XVIII como ponto de partida para a organização de uma biopolítica cujo poder não é incompatível com a razão de Estado (mecanismo de controle). Ao contrário, essas duas lógicas de poder encontram-se articuladas no poder liberal como "dois polos de desenvolvimento interligados por todo um feixe intermediário de relações", diz Foucault (1999, p. 131): de um lado, as disciplinas como uma anatomopolítica do corpo e, de outro, os controles reguladores ou mecanismos 
de segurança como uma biopolítica da população. Contudo, um quadro ilustrativo do poder liberal em que figurasse apenas estes dois polos estaria incompleto. Com efeito, explicaria apenas o funcionamento da biopolítica sem dar conta desse "algo bem mais amplo" considerado por Foucault como sendo o próprio "quadro geral da biopolítica”, isto é, o liberalismo como nova razão governamental. Daí nosso entendimento de que é preciso introduzir um terceiro elemento intermediário que figurasse não apenas como "feixe de relações", mas também como uma das principais formas dessa economia de poder: o poder pastoral.

É preciso se lembrar de um dado histórico importante: o contexto de nascimento do Estado moderno. Isto é, o momento em que a razão de Estado está se formando é marcado pela crise dos laços de comunidade e de seus fundamentos teológicos e feudais. A antiga estrutura feudal encarava o indivíduo que se isolava ou com suspeita ou com admiração: ao isolar-se, o indivíduo era suspeito de contestação da ordem à qual pertencia ou era admirado pela coragem de viver sozinho em um ambiente social atravessado por conflitos (Duby, 2009, p. 529-530). Como mostrou Schiera (2004), com o processo de centralização do Estado, o indivíduo, que antes agia por intermédio do estamento ao qual se vinculava, ganha uma existência exclusivamente privada. Ocorre com o surgimento do Estado moderno o aparecimento da esfera privada individual e, com ela, a noção de interesse.

No século XVIII dizia-se que depois da descoberta das leis do movimento pela física, as leis do interesse foram a segunda grande descoberta do século. Se o mundo físico é governado pelo movimento, diziam os economistas, é o interesse que governa o mundo moral. Começa a tornar-se evidente que ninguém seria capaz de agir contra seu próprio interesse. "O interesse não mente jamais", dizia-se; basta, portanto, observá-lo de modo a calcular suas ações e nelas indexar o poder político para que o governo torne-se perfeito (Gunn, 1998; Hirschman, 2002). A ideia produziu tanta excitação que imediatamente os economistas a conectaram à lógica do mercado para afirmar que o comportamento dos indivíduos 
é governado pelo interesse de ganhos, de lucro, de benefícios, de utilidades. Nasce a imagem do indivíduo liberal: um sujeito portador de interesses econômicos que se comporta de maneira consciente e refletida, tendo sempre em vista a maior probabilidade de ganhos; um sujeito que calcula sua ação para obter o maior ganho possível.

Tendo em vista esse homem econômico será preciso, acima de tudo, garantir e proteger sua liberdade de ação e de comportamento. É o que explica que o liberalismo tenha assumido inicialmente a versão laisser-faire, laisser-passer: é preciso deixar fazer, deixar ir e vir, deixar agir, deixar movimentar-se. É preciso que os indivíduos compreendidos como homens econômicos possuam toda a liberdade necessária para perseguir seus interesses. Mais do que isso, é preciso, acima de tudo, fazer com que estes indivíduos persigam seus interesses, isto é, é preciso excitar no indivíduo o "interesse pelo interesse"; é preciso tornar o indivíduo interessado, estimular a se interessarem; resumindo, é preciso banir o desinteresse.

De outro lado, é preciso igualmente direcionar os interesses: cultivar os bons interesses, eliminar os maus interesses; produzir interesses úteis, bloquear os inúteis. Em suma, o liberalismo deve promover um jogo complexo e perpétuo entre interesse e liberdade: cabe ao liberalismo determinar a exata medida na qual "os diferentes interesses, individuais nisso que possuem de divergente uns dos outros, eventualmente opostos uns aos outros, não constituam um perigo ao interesse de todos" (Foucault, 2004b, p. 67). Tomado sob esse aspecto, o liberalismo configura-se como uma técnica de manipulação dos interesses individuais e coletivos que só é possível ocorrer a partir de um espaço de liberdade de ação e de movimento, isto é, de laisser-faire, laisser-passer.

Mas, ao assumir o jogo dos interesses individuais como alvo político, o exercício do poder liberal assume necessariamente um caráter individualizante que exigirá um conhecimento analítico, detalhado e minucioso sobre os indivíduos para apreender, manipular, suscitar, induzir seus interesses. Até então, a velha razão 
de Estado não exigia um conhecimento analítico sobre os indivíduos, demandava simplesmente um conhecimento estatístico; seu alvo não era o jogo dos interesses individuais, mas unidades: o território, seus habitantes, suas riquezas etc. No Estado liberal governamentalizado, o conhecimento sobre os objetos do governo alcança um nível analítico profundo, na medida em que se trata de fazer com que os interesses individuais sejam induzidos, fomentados, estimulados e, ao mesmo tempo, integrados em uma espécie de totalidade representada pela economia, pelo mercado, pelo comércio etc. Como manipular ou como conduzir a conduta desses sujeitos vivendo nesse espaço de liberdade de ação e de movimento? Como governar esse homem econômico sem destruir nele a liberdade de ação e de movimento? Em outras palavras, como fazer com que o sujeito liberal seja ao mesmo tempo livre para jogar o jogo do mercado e suficientemente obediente às regras deste mesmo jogo?

Tarefa difícil que o liberalismo realizou retomando em seu processo de governamentalização do Estado um antigo poder que antes estava circunscrito aos monastérios, aos conventos, às práticas religiosas: o poder pastoral. Um tipo de poder que é, de certa forma, oposto ao poder da razão de Estado: na disciplina, embora seu alvo seja o corpo, ela não se dirige ao indivíduo como dado primeiro, mas às multiplicidades. Operários, estudantes, soldados etc. são multiplicidades a serem recortadas, classificadas, uniformizadas pela disciplina fabril, escolar, militar etc. O poder pastoral, ao contrário, é um poder estritamente individualizante: "nenhuma ovelha é indiferente. Nenhuma deve escapar a esse movimento, a essa operação de direção e de condução que leva à salvação. A salvação de cada uma é absolutamente importante" (Foucault, 2004a, p. 172). O poder pastoral ocupa-se de omnes et singulatim, todos e cada um. Poder absolutamente novo na história: durante toda a Antiguidade, até a institucionalização do Cristianismo, o poder dos reis ou dos magistrados tinha por objetivo salvar sempre totalidades: o Estado, o território, a cidade, a massa dos cidadãos. Com o Cristianismo, surge um tipo de 
poder que não se ocupará com totalidades: o bom pastor será aquele capaz de "velar pelos indivíduos em particular, sobre os indivíduos tomados um a um. Seu poder não é um poder global" (Foucault, 2001, p. 562).

A natureza individualizante do poder pastoral é seu traço mais importante, na medida em que implica uma responsabilidade analítica do pastor e ao mesmo tempo uma hermenêutica do sujeito. Em outras palavras, implica a condução da conduta e o conhecimento exaustivo do sujeito conduzido. O pastorado requer um conhecimento pleno e total de cada uma das ovelhas pelo pastor para que possa saber empregar os meios para salvação do rebanho na sua totalidade plena. E as técnicas que o Cristianismo utilizou para assegurar ao pastor o conhecimento individual de cada ovelha foram o exame e a direção de consciência. Daí a importância da confissão (conforme Avelino, 2014; 2015).

Esse poder individualizante do pastorado cristão foi retomado pelo liberalismo que a ele justapôs outro poder, desta vez totalizante, mas que não assumiu a forma unitária da razão do Estado e a forma centralizada do corpo do príncipe. Um poder que tem por referência não o corpo do príncipe, mas outro corpo bem mais complexo: o corpo da população. A biopolítica é um poder totalizante que tem por referência não o Estado, mas a população. Ao contrário do pastorado, a biopolítica estabelece um conhecimento sobre os indivíduos que não é analítico: no conhecimento biopolítico, os indivíduos serão definidos a partir do campo econômico em que vivem, quer dizer, serão definidos a partir do número de habitantes, das taxas de longevidade, natalidade, mortalidade, saúde etc. A biopolítica apenas levará em conta o indivíduo considerando-o a partir daquilo que o define como membro de uma população, isto é, a partir daquilo que "permite mesurar quantitativamente os efeitos de massa dos comportamentos individuais" (Foucault, 2001, p. 551). Como observou Lemke (2011), o objeto da biopolítica não são os seres humanos individuais, mas seus aspectos biológicos mensurados e agregados no nível da população. É nesse sentido que a biopolítica torna a vida um fator 
objetivo mensurável e uma realidade coletiva epistemologicamente distinta com a finalidade de majorar suas forças vitais.

Embora Foucault tenha sugerido o poder biopolítico como o que existe de mais específico na racionalidade liberal, seria possível afirmar, entretanto, que a biopolítica apenas é capaz de produzir efeitos eficazes quando associada e justaposta ao poder pastoral. $\mathrm{E}$, com isso, seria permitido sustentar que todo o êxito político do liberalismo repousa nessa sofisticada justaposição entre, de um lado, um poder pastoral individualizante e, de outro, um poder biopolítico totalizante. Se o alvo deste último são os corpos e as forças vitais dos indivíduos considerados como membros de uma população, o alvo do primeiro é precisamente constituído por esse elemento que tem por função tomar os seres humanos como indivíduos: o desejo. Justaposto à biopolítica, o poder pastoral foi responsável por investir sobre a subjetividade dos indivíduos para constituí-los como sujeitos; sua função propriamente liberal é a de produzir a objetivação e a subjetivação de um sujeito governável.

\section{Algumas considerações finais}

O fato de não ser possível existir, em um regime político liberal, a gestão biopolítica da vida sem uma pastoreação do vivo indica o quanto a racionalidade liberal, tomada como instância reflexiva para a objetivação e a subjetivação de um sujeito governável, permite recolocar na ordem do dia toda a importância política da subjetividade e sua relação com a verdade. A genealogia do liberalismo mostra como sua configuração assumiu igualmente uma forma de tecnologia política, cuja incidência recobre a vontade, a alma, a consciência, o eu, e cujo exercício ocorre a partir de práticas de si e processos de subjetivação, tais como técnicas de interiorização, de tomada de consciência etc., com o objetivo de conduzir o indivíduo a reconhecer a si mesmo como sujeito no interior da prática política.

Um dos grandes méritos do método genealógico foi o de ter mostrado as continuidades e as descontinuidades entre o sujeito do liberalismo político, o homo juridicus ou sujeito de direito, e 
o sujeito do liberalismo econômico, tanto do laisser-faire quanto do neoliberalismo contemporâneo, o chamado homo economicus ou sujeito de interesse. São dois tipos de sujeito irredutíveis e antitéticos entre si. No liberalismo político, a constituição do sujeito ocorre pelo instrumento negativo da renúncia contratual. O contrato não apenas funda a soberania, mas também, e sobretudo, os sujeitos a ela submetidos por laços de direitos e deveres de obediência. Basta observar o que disse Hobbes a esse propósito: ao renunciar à própria vontade, o indivíduo "o faz em consideração a outro direito que reciprocamente lhe foi transferido, ou a qualquer outro bem que daí espera. Pois é um ato voluntário, e o objetivo de todos os atos voluntários dos homens é algum bem para si mesmos" (Hobbes, 2003, p. 115).

Como se sabe, em Hobbes, esse bem é a proteção da vida e dos meios de preservá-la. Em todo caso, trata-se de um procedimento que pode ser facilmente remetido ao dispositivo pastoral da direção de consciência: ambos exigem certo rito de produção da verdade (uma aleturgia), no qual se deve renunciar à própria vontade, substituindo-a pela vontade de um outro. Em ambos encontra-se o mesmo tipo de paradoxo ou de cinismo político: no primeiro, para salvar a vida, o indivíduo deve renunciar à sua vontade, do que resultará um poder de morte entregue a um terceiro; no segundo, para salvar a alma, o indivíduo deve igualmente renunciar à sua vontade para que a verdade de si mesmo possa ser produzida por um outro (conforme Foucault, 2012; Avelino, 2014; 2015).

Em relação ao sujeito do liberalismo econômico e do neoliberalismo, ocorre algo bastante diverso. Sua constituição dá-se menos por um instrumento negativo de renúncia do que pela mecânica positiva de um interesse considerado como um dado natural, pelo primeiro, e, pelo segundo, como um produto ambiental, mas considerado por ambos como obedecendo a uma mecânica que, em vez de renúncia, produz a afirmação de comportamentos econômicos. Essa transformação na teoria do sujeito, percebida por Foucault como uma das mais importantes já ocorridas no 
pensamento ocidental desde a Idade Média, acarreta consequências fundamentais para o exercício do poder político.

Como vimos, no liberalismo econômico o sujeito de interesse é o dado natural frente ao qual o governo deve cessar de ser governo. Nele o homo economicus surge frente ao exercício do poder político como alguém que o governo deve deixar fazer e, ao mesmo tempo, sobre quem se deve estimular, incitar, excitar a fazer. No liberalismo econômico, o interesse aparece em relação ao governo, simultaneamente, como consciência individual e como interesse da população (Foucault, 2004a, p. 300). Em outras palavras, como interesse daquilo que o sujeito quer e que deve estar sujeito à proteção, portanto, excluído do campo da ação governamental, e como o interesse inconsciente do que uma população quer, devendo ser tomado como objeto da própria ação governamental.

Já no neoliberalismo, o sujeito de interesse não aparece como dado, mas como produto ambiental. Nesse sentido, o interesse não pode estar nem sujeito à proteção nem ser objeto de gestão governamental, deve ser produzido por uma ambientalização. A intervenção governamental deverá focar, sobretudo, o ambiente e tudo o que nele existe como variável ambiental para a produção de comportamentos econômicos. Nesse aspecto, o neoliberalismo promove uma desnaturalização radical do interesse. O interesse não é mais um dado natural a ser protegido; não aparece mais sob a forma da vontade cujo princípio seria formado por escolhas individuais irredutíveis e intransferíveis referidas ao próprio sujeito. Para o neoliberalismo, não é verdade que o comportamento do homo economicus seja naturalmente econômico, mas poderá sê-lo se encontrar o ambiente necessário. O interesse é simplesmente o que se produz a partir de certas variáveis encontradas em determinado ambiente. Consequentemente, não é preciso mais imaginar a existência de uma parte nos indivíduos que deveria ser intocada, protegida, imune, inacessível à ação governamental. Seja sua vida coletiva como espécie ou os aspectos mais íntimos da sua existência como indivíduo, nada deve escapar à ação do governo. 
Com isso, o neoliberalismo inaugura uma nova prática política a partir da qual o foco da ação governamental será deslocado de uma liberalização da vida da população para uma neoliberalização ampla e radical do indivíduo vivo. Na sua desnaturalização do interesse, o neoliberalismo provocou uma extraordinária politicização do desejo. Em 1996, Gary Becker abriu seu estudo sobre a contabilidade do gosto, afirmando que, embora os economistas tenham levado em consideração as preferências individuais em suas análises, deram pouca atenção à estrutura em si da preferência. Desse modo, diz Becker, o desafio da economia hoje é o de expandir a velha abordagem econômica, preservando seu poder analítico, isto é, retomar a proposição segundo a qual:

[...] os indivíduos se comportam de maneira a maximizar o interesse [utility], porém estendendo a definição da preferência individual para nela incluir hábitos e vícios pessoais, grupos de pressão, influência paterna sobre o gosto das crianças, propaganda, amor e simpatia, além de outros comportamentos negligenciados. Essa extensão da abordagem da "maximização-do-interesse" para incluir nela preferências endógenas é visivelmente bem-sucedida em unificar uma ampla classe de comportamentos, incluindo comportamentos habituais, sociais e políticos. Eu não acredito que qualquer outra abordagem - seja ela fundada em forças "culturais", "biológicas" ou "psicológicas" - seja capaz de fornecer comparável poder de compreensão e explicação (Becker, 1996, p. 4).

Mas como ampliar a abordagem? A fórmula apresentada por Becker é bastante simples: na medida em que o interesse não é um dado natural ou subjetivo mais ou menos latente no interior dos indivíduos, mas produto do meio, logo, basta ampliar suas variáveis. Por exemplo, o interesse por bens de consumo depende de um grande número de variáveis além das propriamente econômicas: o interesse por certa vestimenta não provém apenas da 
necessidade de se vestir, mas depende, em grande medida, de como os outros se vestem; o consumo de álcool hoje depende do quão exageradamente ou não se consumiu álcool ontem; o modo como uma pessoa vota depende muito de como seus amigos votam; o desejo por produtos depende consideravelmente de uma propaganda bem-sucedida etc. Desse modo, além das simples variáveis representadas pelos bens de consumo, é preciso acrescentar as variáveis capital pessoal e capital social - elas mesmas produzidas por inúmeras outras variáveis, tais como infância e educação. Assim, uma abordagem estendida do interesse será expressa pela fórmula: interesse $=i\left(x_{\mathrm{t}}, y_{\mathrm{t}}, z_{\mathrm{t}}, P_{\mathrm{t}} S_{\mathrm{t}}\right)$, onde $x, y$ e $z$ representam diferentes bens de consumo (Becker, 1996, p. 5).

O que é significativo a se perceber é como a análise de Becker transforma o interesse em uma função: nem princípio subjetivo, nem lei natural, o interesse é simplesmente "uma maneira proveitosa para explicar e analisar o comportamento" (Becker, 1996, p. 6). Entretanto, uma função que permite incluir na abordagem do interesse "não apenas bens ordinários como roupas e maçãs, mas também propaganda, educação e outras determinantes das preferências frequentemente não considerados como 'bens"' (op. cit.). Afinal, diz Becker, uma abordagem mais cuidadosa mostraria que "o interesse não depende diretamente dos bens de consumo e estoques de capital, mas apenas da produção doméstica de 'matérias-primas' ['commodities'], tais como saúde, reputação, posição social e os prazeres do sentido" (op. cit. p. 5).

O neoliberalismo não rejeita, portanto, o velho laisser-faire, tal como fizeram os teóricos do Welfare; corrige apenas seu naturalismo ingênuo. Mas faz de tal modo que a função do interesse transforme-se no próprio fundamento de todo e qualquer comportamento individual e em todos os seus aspectos, do amor materno ao uso de entorpecentes. A partir disso, a tarefa do poder político não é tanto a de proteger ou produzir comportamentos, mas de corrigi-los, estimulá-los, ajustá-los a partir da manipulação do próprio sujeito e das variáveis encontradas no seu ambiente econômico. Tarefa infinita sem a qual nada garantiria que o sujeito 
de interesse pudesse sustentar comportamentos econômicos. Com o neoliberalismo, a ação governamental sobre o homo economicus passa de um estado de passividade política para uma condição de superatividade teórica: a economia cessa de funcionar como mero princípio de autolimitação da ação governamental para se tornar o filtro, uma técnica de aferir a ação governamental em termos puramente econômicos. Foi o que Foucault (2004b, p. 252-253) chamou de "cinismo de uma crítica mercantil oposta à ação do poder público" e "tribunal permanente face ao governo".

A evocação do liberalismo econômico e do neoliberalismo pela análise de Foucault teve claramente o propósito de marcar a distância entre os tipos de governamentalidade que eles implicam, com a exigida pelo liberalismo político e seu instrumento negativo da renúncia contratual e seu correspondente dispositivo pastoral da direção de consciência. Em outras palavras, Foucault mostrou a distância que separa, de um lado, o sujeito do liberalismo político, constituído ou que se constitui a si mesmo por um processo negativo de renúncia de si e da própria vontade frente ao exercício do poder político; e, de outro lado, o sujeito do liberalismo econômico e do neoliberalismo cuja constituição ou autoconstituição toma a forma positiva da afirmação de si necessária e indispensável para o próprio exercício do poder político. O ponto de separação está entre um sujeito que renuncia e outro que afirma a si mesmo. No final do seminário intitulado As técnicas de si, pronunciado na Universidade de Vermont (Estados Unidos), em 1982, Foucault concluía dizendo o seguinte:

durante toda a história do Cristianismo um vínculo foi estabelecido entre a revelação, teatral ou verbal, de si e a renúncia do sujeito a ele mesmo. [...] A partir do século XVIII até nossos dias, as "ciências humanas" reinseriram as técnicas de verbalização em um contexto diferente, fazendo delas não mais instrumento de renúncia do sujeito a si mesmo, mas o instrumento positivo para a constituição de um novo sujeito. Que a utilização dessas técnicas tenha 
cessado de implicar a renúncia do sujeito a ele mesmo constitui uma ruptura decisiva (Foucault, 1994b, p. 813).

A ruptura consiste, portanto, no fato de que as ciências humanas, entre as quais certamente a economia política, forneceram um novo contexto para as técnicas de verbalização cristãs no qual não será mais necessária a renúncia do sujeito a si mesmo. Ruptura em direção a um desassujeitamento do sujeito? É o que desejaria os autores mencionados no início deste artigo. Contudo, trata-se da reinserção destas técnicas de verbalização em uma nova forma de sujeição. Em relação ao neoliberalismo, por exemplo, a sujeição assume a forma de uma ambientalização. Becker e Murphy deram um exemplo bastante ilustrativo. Considere um comportamento economicamente importante como a honestidade. Pode acontecer que, em certo ambiente social, as desvantagens para sustentar um comportamento honesto superem suas vantagens. Nesse momento, uma pessoa só preferirá se comprometer com a honestidade apenas por "ligação" ("hardwiring"). "Uma maneira de fazer isso é ter o 'gosto' pela honestidade construído no interior das preferências. Assim, as preferências comprometeriam uma pessoa para agir honestamente mesmo quando a honestidade não 'compensar"' (Becker e Murphy, 2000, p. 144).

Desse modo, tendo em vista que as pessoas possuem liberdade ilimitada de escolha, mas que, no entanto, "as pessoas não podem 'escolher' simplesmente os valores que querem, mas apenas obter os valores vinculados [hardwired] às suas preferências" (Becker e Murphy, 2000), basta orientar suas preferências para que se produza um enforcement da lei. Tome-se o exemplo anterior, porém agora no contexto de uma comunidade zelosa em fazer predominar a honestidade e o respeito à propriedade. As famílias proprietárias serão, obviamente, mais interessadas em encorajar comportamentos honestos e de respeito à propriedade.

Elas tentarão estabelecer e reforçar leis contra o roubo e desencorajar resistências contra a ordem social e econômica. 
Elas podem contratar policiais, guardas e exércitos privados, e impor punição aos transgressores. Mas essas famílias das classes altas seriam mais eficientes se pudessem superar o curso dessas tendências e agir coletivamente (Becker, 1996, p. 226).

Assim, essas famílias poderiam, por exemplo, subsidiar o clero, pagar pela sede e outras despesas das Igrejas que promovam entre as classes baixas normas favoráveis às classes altas. Uma ideia que Becker expressa facilmente na seguinte função-interesse: $\mathrm{i}=\mathrm{i}(\mathrm{x}$, $\mathrm{n}, \mathrm{y})$, onde i é o interesse dos membros das classes baixas, $\mathrm{x}$ são os bens privados obtidos pela audiência de uma Igreja, n são as normas ali criadas e y outros bens. "Sermões e outras atividades clericais reforçam x e também n" (Becker, 1996, p. 227). Logo, a questão é por que membros de uma Igreja aceitariam ouvir sermões que reforçariam normas que diminuem seu interesse? Segundo Becker, "eles estarão dispostos a absorver as normas que diminuem seu interesse apenas se os bens privados $(x)$ forem suficientemente subsidiados. [Quando isso ocorrer], os fiéis deverão absorver as normas produzidas pela Igreja se quiserem consumir os bens privados por ela produzidos" (op. cit. p. 228). E o resultado é que "ninguém sai prejudicado quando as normas se tornam parte das preferências" das classes baixas, na medida em que elas "voluntariamente as aceitam como parte de suas preferências", concluem Becker e Murphy (2000, p. 147, grifos dos autores).

Como buscamos mostrar em um trabalho anterior (Avelino, 2013, p. 189), o aspecto significativo desta economia de poder é que ela "extrai do meio ambiente tanto a energia necessária ao seu funcionamento quanto as informações necessárias para a utilização da energia que a faz funcionar". É um modelo de poder governamental capaz "de retroalimentar incessantemente suas decisões políticas pelas respostas obtidas no ambiente. Assim compreendido, o sistema assume a função básica de distribuidor dos valores políticos no ambiente social de maneira interativa”. Nesse sentido, é uma economia de poder cujas motivações têm pouco a ver com algum cinismo político ou arbítrio 
governamental, como observaram Castel et al. (1978, p. 357), mas muito com pessoas privadas, personalidades religiosas, associações filantrópicas, grupos de assistência, pequenos empresários etc. Sobre todas essas variáveis, a intervenção ambiental permitirá estabelecer aquilo que em outras condições exigiria:

[...] uma extraordinária implantação de regulamentos policiais para alcançar os resultados a que chegaram quase espontaneamente todos os dispositivos de investigação, vigilância, assistência eintervenção preventiva, implementados em nome de projetos filantrópicos ou científicos de saúde e segurança, envolvendo mais frequentemente autênticos intérpretes da maioria silenciosa ou investigadores "objetivos" do que agentes pagos pelo FBI ou CIA, ou mesmo funcionários responsáveis pela aplicação de qualquer política oficial (Castel et al., 1978, p. 354).

Em outras palavras, o neoliberalismo forneceu ao poder político uma racionalidade governamental que permitiu integrar à economia um amplo conjunto de técnicas comportamentais. Permitiu articular aos princípios da economia um extenso campo de práticas de condução das condutas. Foi esse tipo de "ambientalidade aberta às vicissitudes", na expressão de Foucault, o que permitiu indexar ao comportamento econômico toda e qualquer conduta não econômica que - única exigência! - não seja indiferente aos estímulos do ambiente. A partir disso, a tarefa do governo será a de ajustar sua política a princípios e técnicas de intervenção ambiental, de modo que, na ação sobre o ambiente, os indivíduos possam responder "sistematicamente às modificações sistemáticas que se introduzirão artificialmente no meio".

Percebe-se como, nesse ambiente em que o indivíduo torna-se "alguém eminentemente governável" (Foucault, 2004b, p. 274), a liberdade não pode ser a realização de qualquer aspiração política, humana ou cultural; a liberdade resulta simplesmente da posição de indivíduos autônomos autogovernados, devidamente 
equipados racionalmente e movidos por um autointeresse inefável (Mirowski, 2009, p. 437). Além disso, infância, educação, sexualidade, uso de drogas, a relação com outros seres vivos e com o planeta, e também o amor, a amizade, a simpatia, até mesmo a morte, deixam de integrar o campo de experiência possível dos indivíduos para se tornarem bens de consumo, investimentos em capital humano. No ambiente neoliberal não há experiência de si possível, na medida em que não há nele comportamento que não seja resposta a estímulos ambientais.

Depois de tudo, entre o monge imaginado pelo Cristianismo do século $\mathrm{V}$, para o qual cada gesto assumia o valor e a forma de uma resposta-ordem (Foucault, 2012), e o homo economicus imaginado pelo neoliberalismo de nossos dias, para o qual cada gesto assume o valor e a forma de uma resposta-estímulo (Foucault, 2004b), existe realmente uma diferença importante: enquanto a dependência do primeiro era o resultado de um jogo complexo de transformação da subjetividade, no qual o sujeito é conduzido a renunciar a si para constituir em relação a si uma vontade de nada querer por si mesmo; já a liberdade do segundo não requer nenhuma experiência transformadora do sujeito, tampouco qualquer constituição de vontade, exige, ao contrário, a superposição vontade-razão, a coincidência desejo-racionalidade. Em outras palavras, enquanto a dependência do monge - também a do homo juridicus, o sujeito de direito do liberalismo político - era ainda capaz de produzir uma vontade de nada querer; a liberdade do homo economicus provoca um nada de vontade, a completa elisão ética pela assimilação da vontade nas racionalidades econômicas.

Foi talvez antevendo a pálida existência desse indivíduo neoliberal que, em 1864, Dostoiévski (2008) perguntava-se, com uma voz do sangue: o que é esse indivíduo sem desejos, sem caprichos, sem vontade, sem seu próprio querer, senão algo semelhante a uma tecla de piano? É verdade que o insolente anti-herói de Dostoiévski foi retratado pelo autor como o representante de uma geração moribunda de "homens supérfluos" vivendo os últimos 
momentos da sua vida. Teria essa geração desaparecido completamente em nossos dias?

\section{Referências}

ALLEN, Amy. Foucault and enlightenment: a critical reappraisal. Constellations, v. 10, n. 2, p. 180-198, 2003.

ARENDT, Hannah. Origens do totalitarismo: anti-semitismo, imperialismo, totalitarismo. Tradução de Roberto Raposo. São Paulo: Cia. das Letras, 2009.

AUDIER, Serge. Penser le "néolibéralisme". Le moment néolibéral, Foucault et la crise du socialisme. Lormont: Le Bord de Leau, 2015.

AVELINO, Nildo. Governamentalidade e anarqueologia em Michel Foucault. Revista Brasileira de Ciências Sociais, v. 25, n. 74, p. 139-157, 2010.

. Democracia e educação na constituição do sujeito liberal. Educação, v. 36, n. 2, p. 180-191, 2013.

- Sujeito a política: tecnologia confessional e controle da subjetividade. In: AVELINO, Nildo; VACCARO, Salvo (Orgs.). Governamentalidade |Segurança. São Paulo: Intermeios, 2014.

. Confession and political normativity: control of subjectivity and production of the subject. Soft Power, v. 2, n. 1, p. 15-38, 2015.

AVELINO, Nildo; VACCARO, Salvo. Apresentação. In:

(Orgs.). Governamentalidade | Segurança. São Paulo: Intermeios, 2014. p. 7-11.

BECKER, Gary. Accounting for tastes. Cambridge: Harvard University Press, 1996.

BECKER, Gary; EWALD, François; HARCOURT; Bernard. Becker on Ewald on Foucault on Becker. The Carceral Notebooks, v. 7, 2011. Disponível em: <http://www.thecarceral.org/journal-vol7. html $\geq$. Acesso em: 9 dez. 2015.

Foucault. Socio, n. 3, p. 265-288, 2014.

- Gary Becker dialogue avec Michel . Becker et Foucault sur les délits et les

peines. Socio, n. 5, p. 193-220, 2015. 
BECKER, Gary; MURPHY, Kevin. Social economics: market behavior in a social environment. Cambridge: Harvard University Press, 2000.

BEHRENT, Michael. Le libéralisme sans l'humanisme: Michel Foucault et la philosophie du libre marché, 1976-1979. In: ZAMORA, Daniel (Ed.). Critiquer Foucault: les années 1980 et la tentation néolibérale. Bruxelas: Les Éditions Aden, 2014. p. 37-85. Can the critique of capitalism be antihumanist? History and Theory, n. 54, p. 372-388, 2015.

BONNAFOUS-BOUCHER, Maria. Un libéralisme sans liberté: pour une introduction du terme "libéralisme" dans la pensée de Michel Foucault. Paris: L'Harmattan, 2001.

BOURDIEU, Pierre. L'illusion biographique. Actes de la Recherche en Sciences Sociales, v. 62, n. 1, p. 69-72, 1986.

BUTLER, Judith. What is critique? An essay on Foucault's virtue. In: SALIH, Sara (Ed.). Judith Butler reader. Oxford: Blackwell, 2004. p. 302-322.

CALLIGARIS, Contardo. Anarquistas, neoliberais e Foucault. Folha de São Paulo, 6 jun. 2013.

CANNING, Joseph. A history of medieval political thought (3001450). London: Routledge, 1996.

CASTEL, Robert et al. La société psychiatrique avancée: le modèle américain. Paris: Grasset, 1978.

CHRISTOFFERSON, Michael S. Foucault et la "nouvelle philosophie": pourquoi Michel Foucault soutient les maîtres penseurs d'André Glucksmann. In: ZAMORA, Daniel (Ed.). Critiquer Foucault: les années 1980 et la tentation néolibérale. Bruxelas: Les Éditions Aden, 2014. p. 13-35.

COHN, Gabriel. Crítica e resignação: Max Weber e a teoria social. São Paulo: Martins Fontes, 2003.

COLLIOT-THÉLĖNE, Catherine. Modern rationalities of the political: from Foucault to Weber. Max Weber Studies, v. 9, n. 1-2, p. 165-187, 2009.

DAHL, Robert. Poliarquia. Tradução de Celso M. Paciornik. São Paulo: Edusp, 2012. 
DEAN, Mitchell. Michel Foucault's "apology" for neoliberalism. Journal of Political Power, v. 7, n. 3, p. 433-442, 2014.

. Foucault must not be defended. History and Theory, n. 54, p. 389-403, 2015.

DONZELOT, Jacques. Michel Foucault et l'intelligence du libéralisme. Sprit, Paris, n. 319, p. 60-81, 2005.

DOSTOIÉVSKI, Fiódor. Memórias do subsolo. 5. ed. Tradução de Boris Schnaiderman. São Paulo: Ed. 34, 2008.

DUBY, Georges. A emergência do indivíduo. A solidão nos séculos XI-XIII. In: ___ (Org.). História da vida privada: da Europa feudal à Renascença. São Paulo: Cia. das Letras, 2009. v. 2, p. 503526.

ELIAS, Norbert. O processo civilizador: uma história dos costumes. Tradução de Ruy Jungman. Rio de Janeiro: Zahar, 1996. v. l.

ESPOSITO, Roberto. Totalitarisme ou biopolitique. Tumultes, v. 1, n. 26, p. 9-20, 2006.

FREDERICO II, O Grande. O anti-Maquiavel. Tradução de Ivone C. Benedetti. São Paulo: Martins Fontes, 2014.

FOUCAULT, Michel. L’archéologie du savoir. Paris: Gallimard, 1969. . Qu'est-ce que la critique? [Critique et aufklärung]. Bulletin de la Société Française de Philosophie, a. 84, t. LXXXIV, n. 2, p. 35-63, 1990.

. Dits et écrits: 1976-1979. Paris: Gallimard, 1994a. v. III. . Dits et écrits: 1980-1988. Paris: Gallimard, 1994b. v. IV. . História da sexualidade: a vontade de saber. 13. ed. Tradução de Maria Albuquerque e José Augusto Guilhon Albuquerque. Rio de Janeiro: Graal, 1999.

. Dits et écrits: 1976-1988. Paris: Gallimard, 2001a. v. II. . Fearless speech. Los Angeles: Semiotext(e), 2001b.

. Sécurité, territoire, population: cours au Collège de France (1977-1978). Paris: Gallimard/Seuil, 2004a.

- Naissance de la biopolitique: cours au Collège de France (1978-1979). Paris: Gallimard/Seuil, 2004b.

. Le gouvernement de soi et des autres: cours au Collège de France (1982-1983). Paris: Gallimard/Seuil, 2008. 
. Du gouvernement des vivants: cours au Collège de France (1979-1980). Paris: Gallimard/Seuil, 2012.

GAGO, Verónica. ¿Últimas palavras? Clarín, 3 out. 2015.

GEORGI, Frank. Construire l'autogestion. In: Autogestion: la dernière utopie? Paris: Publications de la Sorbonne, 2003. p. 11-27.

GUNN, John Alexander Wilson. L'intérêt ne ment jamais: une maxime politique du XVIIe siècle. In: LAZZERI, Christian; REYNIÉ, Dominique (Eds.). Politiques de l'intérêt. Paris: Les Belles-Lettres, 1998. p. 193-207.

HABERMAS, Jurgen. O discurso filosófico da modernidade: doze lições. Tradução de de Luiz S. Repa e Rodnei Nascimento. São Paulo: Martins Fontes, 2000.

HAYEK, Friedrich August von. The road to serfdom. New York: Routledge, 2006.

HIRSCHMAN, Albert. As paixões e os interesses: argumentos políticos a favor do capitalismo antes do seu triunfo. Tradução de Luiz G. B. Chaves e Regina Bhering. Rio de Janeiro: Record, 2002. HOBBES, Thomas. Leviatã. Tradução de João Monteiro e Maria B. N. da Silva. São Paulo: Martins Fontes, 2003.

JOYEUX, Maurice. Le congrès de la CFDT: un tournant dans le monde syndical! Le Monde Libertaire, n. 162, 1970. Disponível em: <http://www.monde-libertaire.fr/>. Acesso em: 9 dez. 2015.

KOOPMAN, Colin. Genealogy as critique: Foucault and the problems of modernity. Indiana: Indiana University Press, 2013.

LAGASNERIE, Geoffroy. La dernière leçon de Michel Foucault: Sur le néoliberalisme, la théorie et la politique. Paris: Fayard, 2012.

Néolibéralisme, théorie politique et pensée critique. Raisons Politiques, v. 4, n. 52, p. 63-76, 2013.

. Monstruosités critiques et surdités politiques: réponse à un article publié dans Clarín à propos de la dernière leçon de Michel Foucault. Le site de Geoffroy de Lagasnerie, 2015. Disponível em: $<$ http://geoffroydelagasnerie.com>. Acesso em: 9 dez. 2015.

LEFORT, Claude. A invenção democrática: os limites da dominação totalitária. 3. ed. Tradução de Isabel Loureuro e Maria L. Loureiro. Belo Horizonte: Autêntica, 2011. 
LEMKE, Thomas. Biopolitics: an advanced introduction. New York: Nyup, 2011.

MARCUSE, Herbert. O combate ao liberalismo na concepção totalitária do Estado. In: (Org.). Cultura e Sociedade. Tradução de Wolfgang L. Maar. Rio de Janeiro: Paz e Terra, 1997. v. I, p. 47-88.

MEINECKE, Friedrich. L'idée de la raison d'Etat dans l'histoire des temps modernes. Tradução de Maurice Chevallier. Genebra: Droz, 1973.

MIROWSKI, Philip. Postface: defining neoliberalism. In: MIROWSKI, Philip; PLEHWE, Dieter (Eds.). The road from Mont Pelerin: the making of the neoliberal thought collective. Cambridge: Harvard University Press, 2009. p. 417-446.

PAINE, Thomas. Os direitos do homem: uma resposta ao ataque do sr. Burke à Revolução Francesa. Tradução de Jaime Clasen. Petrópolis: Vozes, 1989.

QUESNAY, François. Máximas do governo econômico. In:

(Org.). Quadro econômico dos fisiocratas. Tradução de João G. V. Netto. São Paulo: Victor Civita, 1983. (Coleção Os Economistas). QUIJOUX, Maxime. Néolibéralisme et autogestion: l'expérience argentine. Paris: IHEAL Éditions, 2011.

RAWLS, John. O liberalismo político. Tradução de Dinah de A. Azevedo. São Paulo: Ática, 2000.

RORTY, Richard. Ensaios sobre Heidegger e outros: escritos filosóficos. Tradução de Marco A. Casanova. Rio de Janeiro: Relume Dumará, 1999. v. 2.

SCHIERA, Pierangelo. Lo stato moderno: origini e degenerazione. Bolonha: Clueb, 2004.

SEARLE, John R. Expressão e significado: estudos da teoria dos atos da fala. Tradução de Ana C. G. A. de Camargo e Ana L. M. Garcia. São Paulo: Martins Fontes, 2002.

SENELLART, Michel. La raison d'Etat antimachiavélienne: essai de problématisation. In: LAZZERI, Christian; REYNIÉ, Dominique. (Eds.). La raison d'Etat: politique et rationalité. Paris: PUF, 1992. p. 15-42. 
. As artes de governar. Tradução de Paulo Neves. São Paulo: Ed. 34, 2006.

SMITH, Adam. A riqueza das nações. Tradução de Luiz J. Baraúna. São Paulo: Victor Civita, 1983. (Coleção Os Economistas). v. I. THUAU, Etienne. Raison d'Etat et pensée politique à l'époque de Richelieu. Paris: Albin Michel, 2000.

WEBER, Max. A ética protestante e o espírito do capitalismo. 12. ed. Tradução de M. Irene de Q. F. Szmrecsányi e Tomás J. M. K. Szmrecsányi. São Paulo: Pioneira, 1997.

WEILL, Claudie. La revue Autogestion comme observatoire des mouvements d'émancipation. L'Homme et la Société, v. 132, n. 2, p. 29-36, 1999.

ZAMORA, Daniel. (Ed.). Critiquer Foucault: les années 1980 et la tentation néolibérale. Bruxelas: Les Éditions Aden, 2014.

\section{Resumo}

O artigo aborda o debate em torno da reflexão de Michel Foucault acerca do liberalismo e do neoliberalismo. Apresenta de maneira critica alguns trabalhos recentes, na França e nos EUA, que têm concluído sobre a existência de afinidades, especialmente teóricas, entre Foucault e o neoliberalismo, apontando suas fragilidades metodológicas. Procura, em seguida, evidenciar a especificidade genealógica que caracteriza a análise foucaultiana em relação às abordagens concernidas com a denúncia ideológica ou com a valorização ideal do liberalismo. Retoma particularmente os estudos da governamentalidade a partir dos quais Foucault realizou uma descrição histórica do liberalismo e do neoliberalismo em termos de racionalidade governamental. Apresenta-se um quadro sintético da economia de poder liberal na análise foucaultiana em que se verifica a superposição de três racionalidades historicamente localizáveis: razão de Estado, poder pastoral, biopoder. O artigo termina com uma leitura das diferenças entre o liberalismo econômico e o neoliberalismo e as implicações de cada um deles no exercício do poder político.

Palavras-chave: liberalismo; neoliberalismo; governamentalidade; racionalidade; crítica. 


\section{Abstract}

The article discusses the debate about Michel Foucault's reflection on liberalism and neoliberalism. It presents critically some recent works in France and the USA that has concluded about the existence of affinities, especially theoretical, between Foucault and neoliberalism, pointing out its methodological fragilities. It then seeks to evidence the genealogical specificity that characterizes the Foucaultian analysis in relation at approaches concerned with a kind of ideological denunciation or ideal valuation of liberalism. It particularly retakes the studies of governmentality from which Foucault describes a historical account of liberalism and neoliberalism in terms of governmental rationality. It presents a synthetic figure of the liberal economy of power in the Foucauldian analysis, in which there is a superposition of three historically localizable rationalities: state reason, pastoral power, biopower. The article ends with a reading of the differences between economic liberalism and neoliberalism and the implications of each of them in the exercise of political power.

Keywords: liberalism; neoliberalism; governmentality; rationality; critique.

Recebido em 24 de agosto de 2015.

Aprovado em 4 de março de 2016. 